\title{
TARGETED KILLING IN INTERNATIONAL LAW: SEARCHING FOR RIGHTS IN THE SHADOW OF 9/11
}

\author{
Dr. Saby Ghoshray* \\ “[T]he bottom line is: 'whose 4-year-olds get killed?',"1

\section{INTRODUCTION}

"After hundreds of drone strikes, how could the United States possibly still be working its way through a 'top 20' list?"2 This exclamation of comical despair from the Pakistani military Chief General Ashfaq Parvez Kayani raises many questions. His quizzical outburst during a recent meeting with his American counterpart, Navy Admiral Michael Mullen, is a telling encapsulation of the continuous saga of military actions. Cloaked under secrecy, these actions fall outside the prescribed limits of international law. Yet, American drone strikes in sovereign territories have largely been ignored within contemporary discourse. ${ }^{3}$ This is predominantly due to the success of military planners in propagating a palatable narrative to the general populace. ${ }^{4}$ This narrative is simple. It provides assurance that drone strikes eliminate known terrorists which in turn makes America safer. ${ }^{5}$ This simple narrative also alleviates the public's concerns about human rights violations by emphasizing that the surgical precision of drone

* Dr. Saby Ghoshray's scholarship focuses on Constitutional Law, International Law, Capital Jurisprudence, Military Tribunals, and Cyberspace law, among others. His work has appeared in Albany Law Review, ILSLA Journal of International and Comparative Law, European Law Journal ERA-Forum, Loyola University Chicago Law Journal, Santa Clara Law Journal, Georgetown International Law Review, Temple Political \& Civil Rights Law, Fordham International Law Journal, and Miami Law Review, to name a few. The author would like to thank Jennifer Schulke for her assistance in legal research and typing of the manuscript, and his beautiful children, Shreyoshi and Sayantan, for their patience and understanding. Dr. Ghoshray can be reached at sabyghoshray@sbcglobal.net.

1. See infra note 7 (quoting Joe Klein in a television interview justifying the usage of drones, even if it kills children).

2. See Greg Miller, Plan for Hunting Terrorists Signals US Intends to Keep Adding Names to Kill Lists, WASH. Post, Oct. 23, 2012, http://articles.washingtonpost.com/2012-1023/world/35500278_1_drone-campaign-obama-administration-matrix, archived at http://perma.cc/365X-DYM3.

3. See Mathew Feeney, Most Americans Are OK with Drone Strikes, Rest of the World Mostly Unconvinced, HIT \& RUN BLOG (Oct. 3, 2012, 4:52 PM), http://reason.com/blog/2012/10/03/most-americans-are-ok-with-drone-strikes, archived at http://perma.cc/N2GJ-YWQR.

4. Larry Everest, The Illegality, Illegitimacy and Immorality of US Drone Strikes, Global ReSEARCH, Nov. 5, 2013, http://www.globalresearch.ca/the-illegality-illegitimacyand-immorality-of-u-s-drone-strikes/5356886, archived at http://perma.cc/WY7Q-7W2Z.

5. $I d$. 
strikes minimizes civilian collateral casualties. ${ }^{6}$

However, this narrative of targeted killing is false. Often times, its convoluted logic relies on pure inhumanity. ${ }^{7}$ Borne out of a faulty conception of American exceptionalism and military hubris, ${ }^{8}$ this narrative gained momentum in the fertile ground of post-9/11 fear psychosis. ${ }^{9}$ It has continued unabated until today. ${ }^{10}$ By placing against the hard rubric of international law, this Article is designed to rescue the narrative of targeted killing by drones from its existing legal framework.

Drones for targeted killing are relatively cheap to build, remotely controlled, and devoid of both emotions and physiological limitations. The Predator drone can strike with deadly finality. ${ }^{11}$ Since a spike in the year 2010, Predator drone strikes continue unabated in Pakistan and Afghanistan. ${ }^{12}$ While the American forces targeted mostly members of AlQaeda and the Taliban, ${ }^{13}$ evidence reveals that the innocent civilians killed

6. See id.

7. See Glenn Greenwald, Joe Klein's Sociopathic Defense of Drone Killings of Children, THE GUARDIAN (Oct. 23, 2012, 11:29 EDT), http://www.theguardian.com/commentisfree/2012/oct/23/klein-drones-morning-joe, archived at http://perma.cc/6SGB-LSJ6.

8. See generally Saby Ghoshray, Guantánamo: Understanding the Narrative of Dehumanization through the Lens of American Exceptionalism and Duality of 9/11, 57 WAYNE L. REV. 163 (2011) [hereinafter Narrative of Dehumanization] (explaining the shaping effect of 9/11 in both American law and social consciousness).

9. Id.

10. See Jo Becker \& Scott Shane, Secret 'Kill List' Proves a Test of Obama's Principles and Will, N.Y. Times, May 29, 2012, http://www.nytimes.com/2012/05/29/world/obamasleadership-in-war-on-al-qaeda.html?pagewanted $=1 \&$ r $=4 \&$ pagewanted $=$ all\&, archived at http://perma.cc/K7HN-B8WD (noting how the Obama administration has been escalating drone strikes while defending civilian killings by employing linguistic innovations).

11. See Christopher Drew, Drones Are Weapons of Choice in Fighting Qaeda, N.Y. TIMES, Mar. 16, 2009, http://www.nytimes.com/2009/03/17/business/17uav.html?_r=1\&hp, archived at http://perma.cc/N96B-LJA9.

12. See Bill Roggio \& Alexander Mayer, Charting the Data for US Airstrikes in Pakistan, 2004 - 2014, THE LONG WAR J., Dec. 25, 2013, http://www.longwarjournal.org/pakistan-strikes.php, archived at http://perma.cc/S24ZVQXF (detailing statistical data which comprises current and past drone strikes in the broader Pakistan region); see also Yochi J. Dreazen, Despite Pakistani Denials, U.S. Keeps Drone Operations Inside Country, NAT'L J. DAILY, July 1, 2011 ("CIA operations at the Shamsi air base in western Pakistan, a short distance from the Afghan border, were continuing unabated and that no American personnel had been withdrawn from the facility. The base is the hub of the CIA's escalating campaign of drone strikes. ..").

13. See generally Int'l Human Rights \& Conflict Resolution Clinic of Stanford Law Sch. (Stanford Clinic) \& The Global Justice Clinic at N.Y. Univ. Sch. of Law (NYU Clinic), Living Under Drones: DeAth, InJuRy and Trauma to CiVilians From US Drone Practices IN PAKISTAN (2012) [hereinafter Living Under Drones], archived at http://perma.cc/HG46-QLLM; see also Jonathan Masters, Targeted Killing, Council on Foreign Relations, May 23, 2013, http://www.cfr.org/counterterrorism/targetedkillings/p9627, archived at http://perma.cc/UCM3-KVFF ("Since assuming office in 2009, 
vastly outnumber the militants. ${ }^{14}$ This ability to fire missiles at enemy targets from unmanned aerial vehicles ("UAVs") ${ }^{15}$ has not only transformed the twenty-first century conflict into an array of ubiquitous battlefields, it has also called into question some of the fundamental assumptions of the law of armed conflict ("LOAC"), or international humanitarian law ("IHL"). ${ }^{16}$ While some commentators have called these killings "extrajudicial," 17 or "targeted," 18 some have also attempted to advance the

Barack Obama's administration has escalated targeted killings, primarily through an increase in unmanned drone strikes on al-Qaeda and the Taliban. ..”).

14. See Living Under Drones; see also Jack Serle, Drone Warfare: More than 2,400 dead as Obama's Drone Campaign Marks Five Years, BUREAU OF INVESTIGATIVE JOURNALISM, Jan. 23, 2014, http://www.thebureauinvestigates.com/2014/01/23/morethan-2400-dead-as-obamas-drone-campaign-marks-five-years/, archived at http://perma.cc/Y3HL-WSQ3. Even if the number of civilian killed has slightly reduced, the number is still substantial when you consider that even as recent as 2009:

Press reports suggest that over the last three years drone strikes have killed about 14 terrorist leaders. But, according to Pakistani sources, they have also killed some 700 civilians. This is 50 civilians for every militant killed, a hit rate of 2 percent - hardly "precision." American officials vehemently dispute these figures, and it is likely that more militants and fewer civilians have been killed than is reported by the press in Pakistan. Nevertheless, every one of these dead noncombatants represents an alienated family, a new desire for revenge, and more recruits for a militant movement that has grown exponentially even as drone strikes have increased.

David Kilcullen \& Andrew McDonald Exum, Op-Ed., Death From Above, Outrage Down Below, N.Y. TIMES, May 16, 2009, http://www.nytimes.com/2009/05/17/opinion/ 17exum.html?_r=1, archived at http://perma.cc/4V2-4EC4 [hereinafter Death From Above].

15. See Death from Above, supra note 14 (noting that the use of drones-a type of unmanned aerial vehicle ("UAV") - in military operations has steadily grown); see also Mary Louise Kelly, Officials: Bin Laden Running Out of Space to Hide, NPR, Jun. 5, 2009, http://www.npr.org/templates/story/story.php?storyId=104938490, archived at http://perma.cc/Z4RQ-QQL6 (stating that the pace and precision of drone attacks has increased steadily); see generally Effective Counterinsurgency: The Future of the USPakistan Military Partnership: Hearing on H.A.S.C. No. 111-43 Before the H. Comm. on Armed Serv., 111th Cong. 7 (2009) (statement of Dr. David Kilcullen, Partner, Crumpton Group, LLC, Senior Fellow, EastWest Institute, Member of the Advisory Board, Center for a New American Security) (discussing the unpopularity of drone strikes and the casualties caused to civilians when using drones for military purposes).

16. By international humanitarian law (IHL), I generally refer to the rich corpus of codified international customs of warfare that has evolved through the centuries and has been modified by various wars in modern times. This phrase is used as a reference to the body of laws governing the conduct of hostilities, such as The Hague and Geneva stream of laws, and therefore, is used synonymously as the laws of armed conflict. See generally Michael E. Howard et Al., The Laws of War: Constraints on Warfare in The Western WORLD (Yale Univ. Press. 1997) (providing general information on the Laws of War); see also Richard Murphy \& Afsheen John Radsan, Due Process and Targeted Killing of Terrorists, 31 CARdozo L. REV. 405, 408-9 (2009).

17. See Special Rapporteur on Extrajudicial, Summary or Arbitrary Executions, Civil and Political Rights, Including the Questions of Disappearances and Summary Executions, Extrajudicial, Summary or Arbitrary Executions, paras. 37, 39, submitted pursuant to Commission on Human Rights resolution 2002/36, U.N. Doc. E/CN.4/2003/3 (Jan. 13, 
legitimacy argument on the pretext of self-defense. ${ }^{19}$ Objective analysis, however, must decouple from rhetoric, and focus on fundamental issues brought up by technology-driven changes in modern warfare.

More than a decade removed from the events of $9 / 11$, targeted killing has now become the de jure of international jurisprudence, largely riding the shadow of $9 / 11$ and more importantly, drawing its legal potency from the occurrence of $9 / 11 .^{20}$ Scholars have defined targeted killing in various ways. Some have provided an expanded definition that includes the "premeditated, preemptive, and intentional killing of an individual or individuals." 21 Some have examined targeted killing within the hostilities framework by encapsulating such actions as falling in a continuum within war. ${ }^{22}$ Few scholars, however, categorized targeted killing as extrajudicial killing within an expanded conception of hostilities. ${ }^{23}$ This Article examines these diverging viewpoints and places the contentious issue of targeted killing on a robust legal framework.

Besides divergence in scholarly viewpoint, targeted killing of terrorism suspects outside of judicial due process has caused much consternation in international law, ${ }^{24}$ and rightfully so. Driven by profound anxieties over the extrajudicial nature of these killings, and an alarm for the complex human rights issues they expose, these acts have already become the focal point of legal controversy. This controversy, however, is not without historical roots. State-sponsored targeted killing is almost as old as international law. The attempt to encapsulate these killings within the interpretative gloss of The Hague and the Geneva streams of international law, however, is rather recent. Prompted by global condemnation of the targeted killing of Palestinian terror suspects by the Israeli Defense Forces

2003), available at http://daccess-dds-ny.un.org/doc/UNDOC/GEN/G03/103/27/PDF/ G0310327.pdf?OpenElement (characterizing the November 2002 killing via drone strikes inside Yemen of Qaeda Sinan Harithi, an alleged planner of USS Cole bombing as extrajudicial).

18. See Murphy \& Radsan, supra note 16, at 406-407.

19. See generally Amos Guiora, Targeted Killing as Active Self-Defense, 36 CASE W. RES. J. INT'L L. 319 (2004).

20. See generally Masters, supra note 13 (noting the post-9/11 legal landscape has allowed targeted killing to become part of legal manipulations in international law).

21. Thomas B. Hunter, Targeted Killing: Self-Defense, Preemption, and the War on Terrorism, 2:2 J. STRATEGIC SEC. 1, 3 (2009), archived at http://perma.cc/JN3V-CU8X.

22. See supra note 19 and accompanying text (while the text examines why the legal community is divided as to the efficacy of the two anti-terrorism models, the work by Professor Guiora attempts to seek legitimacy in targeted killing by self-defense as one of the essential drivers for such an act and thus, conveniently placing such right within a spectrum).

23. See generally Mary Ellen O'Connell, Unlawful Killing with Combat Drones: A Case Study of Pakistan, 2004-2009 (July 2010) (unpublished legal studies research paper, Notre Dame Law School), archived at http://perma.cc/KR9Y-9GJX [hereinafter Unlawful Killing with Combat Drones] (noting that a strike on Yemen in 2003 was concluded to be a clear extrajudicial killing).

24. Id. 
("IDF"), the formalized efforts to legally capture such acts of state violence began in the $1990 \mathrm{~s} .{ }^{25}$ As a result, the framework of customary international law began its normative change to incorporate such state conduct of hostilities, until it encountered one of the biggest stressors in international law in over half a century-the 9/11 terrorist attacks. Subsequently, the post-9/11 global landscape has shaped the theoretical discussions surrounding targeted killing on two main fronts. First, by allowing a de facto blanket approval on pervasive targeted killings by nation states, international law has remained largely complicit. Second, by infusing a nebulous paradigm of "the law of $9 / 11, " 26$ legal justification for targeted killings has transmogrified into an unregulated space within international law. This Article will explore both areas in detail.

Scholarship on targeted killing reveals diverging perspectives. In

25. See Amnesty Int'l, Israel/Gaza: Operation 'CAst Lead': 22 Days of Death AND DESTRUCTION 1 (2009), archived at http://perma.cc/4DED-FWDK ("At 11:30 a.m. on 27 December 2008, without warning, Israeli forces began a devastating bombing campaign on the Gaza Strip codenamed Operation 'Cast Lead.'”). Israeli drones have caused civilian casualties that have gone virtually unnoticed. Id. For example, these remote strikes have caused the loss of thousands of innocent lives during the Israeli incursion in Gaza from December 2008 to January 2009. Id.; see also Robert Perry Barnidge, The Principle of Proportionality Under International Humanitarian Law and Operation Cast Lead, in NEW Battlefields/Old Laws: Critical Debates on Asymmetrical Warfare (William C. Banks ed., 2011) archived at http://perma.cc/PCT2-3VQT (noting that a study conducted by the Israel Defense Force ("IDF") concluded that Operation Cast Lead produced over 1,300 Palestinian casualties); Clancy Chassay, Cut to Pieces: The Palestinian Family Drinking Tea in Their Courtyard, THE GuARDIAN (Mar. 23, 2009, 11:57 EDT), http://www.guardian.co.uk/world/2009/mar/23/gaza-war-crimes-drones, archived at http://perma.cc/8FVE-ARQK (recounting a story of a Palestinian family that was hit by an Israeli drone flying overhead).

26. By the "law of 9/11," I refer to a general trend in the post-9/11 jurisprudence that promotes a broader right to kill and is premised on a US political thought process that is decoupled from the accepted framework of international law. The law of 9/11 can be identified through scholarships premised on US entitlement to a flexible regime that allows for acts, such as, indefinite detention, targeted killing by extrajudicial means, torture in secret CIA prisons, etc. For literature that exemplifies the "law of 9/11" in the context of targeted killing, see, e.g., Kenneth Anderson, Targeted Killing in US Counterterrorism Strategy and Law (The Brookings Institution, Georgetown University Law Center, and the Hoover Institution, Working Paper of the Series on Counterterrorism and American Statutory Law, 2009), archived at http://perma.cc/3WCY-7AM5; Saby Ghoshray, Untangling the Legal Paradigm of Indefinite Detention: Security, Liberty and False Dichotomy in the Aftermath of 9/11, 19 ST. THOMAS L. REV. 249 (2006) [hereinafter Paradigm of Indefinite Detention] (providing a general discussion of how the law of 9/11 has impacted almost every aspect of American Law); Mary Ellen O'Connell, Enhancing the Status of Non-State Actors Through a Global War on Terror?, 43 Colum. J. TRANSNAT'L L. 435 (2005), archived at http://perma.cc/8RBT-RBMD (explaining why the evolving law of 9/11 may fall outside the legal norms of international law); John Yoo, Using Force, $71 \mathrm{U}$. CHI. L. REV. 729 (2004), archived at http://perma.cc/M7UF-X3Z5 (discussing the law of $9 / 11$ in the context of the general US right in global war). 
general, scholars have placed the act of targeted killing within the existing framework of international law via two different pathways. The first pathway traces the rights issue within a complex web of statutory provisions constructed out of the two mainstream international law paradigms: IHL and HRL. ${ }^{27}$ The second pathway attempts to inject legitimacy within the law by mostly invoking an expanded conception of state right premised on post-9/11's Neolithic framework, or the "law of 9/11."28 Regardless of how the legality of targeted killing by drones is crafted, this type of killing stands against the continued relevance of human rights strands within international law. Because such extrajudicial killings are not only asymptotic with human rights law's sanctity of life paradigm, but they also stand in contradiction to customary international law's due process paradigm. ${ }^{29}$ Debate and difficulties notwithstanding, targeted

27. See David Kretzmer, Targeted Killing of Suspected Terrorists: Extra-Judicial Execution or Legitimate Means of Defence, 16:2 EuR. J. INT'L L. 171, 171, 183-192 (2005) [hereinafter Targeted Killing of Suspected Terrorists], archived at http://perma.cc/HL6TE9N (examining the difficulties and relevance in some existing scholarship on targeted killing under both HRL norm and IHL).

28. See generally Philip Alston, The CIA and Targeted Killings Beyond Borders (New York University School of Law, Public Law \& Legal Theory Research Paper Series, Working paper No. 11-64, (2011)), archived at http://perma.cc/XDT6-SC7S (examining in general how post-9/11 awareness has resulted in framing exigencies to legalize targeted killing of suspected terrorists via drone strikes).

29. While discussing the scope distinction between IHL and HRL, there is a tendency of the states to invoke IHL in order to avoid HRL's stricter guidelines for behavior in hostilities while being governed by IHL's more permissive guidelines supervising killing. In this context, Special Rapporteur recently observed:

[B]oth the US and Israel have invoked the existence of an armed conflict against alleged terrorists ("non-state armed groups"). The appeal is obvious: the IHL applicable in armed conflict arguably has more permissive rules for killing than does human rights law or a State's domestic law, and generally provides immunity to State armed forces. Because the law of armed conflict has fewer due process safeguards, States also see a benefit to avoiding compliance with the more onerous requirements for capture, arrest, detention or extradition of an alleged terrorist in another State. IHL is not, in fact, more permissive than human rights law because of the strict international humanitarian law requirement that lethal force be necessary. But labeling a situation as an armed conflict might also serve to expand executive power both as a matter of domestic law and in terms of public support.

Special Rapporteur on Extrajudicial, Summary or Arbitrary Executions, Addendum: Study on Targeted Killings, Human Rights Council, para. 47, U.N. Doc. A/HRC/14/24/Add.6 (May 28, 2010) (by Philip Alston) (alteration added) (internal citations omitted) [hereinafter U.N. Doc. A/HRC/14/24/Add.6]. In the context of the legality of killing, HRL and IHL may apply coextensively and simultaneously unless there is a conflict between them. See Special Rapporteur on Extrajudicial, Summary or Arbitrary Executions, Civil and Political Rights Including the Questions of Disappearances and Summary Executions, Comm'n on Human Rights, para. 50, U.N. Doc. E/CN.4/2005/7 (Dec. 22, 2004) (by Philip Alston) [hereinafter U.N. Doc. E/CN.4/2005/7]; Special Rapporteur on Extrajudicial, Summary or Arbitrary 
killing, therefore, raises intriguing questions of law and philosophy. Where does the act fall within the rights framework? Does it have explicit legal support within the manifold of legal strands that constitute international law? Does 9/11 necessitate recognizing a derivative right within international law that takes the form of targeted killing? This Article seeks these answers.

To interject a more comprehensive revelatory gloss into the emerging menace of targeted killing, I approach this from a right-based paradigm. Because any act motivated and sanctioned by law must claim its force from some right. This inquiry will, therefore, focus on whether targeted killing, as a right, falls within the rights manifold of international law. For it to be legitimized within international law, the act of targeted killing must be a manifestation of an expressed right within such law. Guided by an understanding of the shaping effect of $9 / 11$ on emerging jurisprudence, ${ }^{30}$ this study goes beyond a limited dimensional security-centric analysis, in the process placing such right within the broader rubric of international law.

A right-based analysis will provide additional clarity for normative reasons. Governments engaged in targeted killings often provide an ex post facto explanation without a component level analysis of such acts. This provides neither clarity, nor legitimacy. By mapping the acts of targeted killing within a binary rights framework, it is possible to conceptualize a right as either falling within or outside the existing manifold. Identifying the former could allow us to construct a framework, if needed, to incorporate such rights by any one of the existing pathways through which various rights within international law have been conceived. Identifying the latter may propel us to conclude that such rights of targeted killing in their

Executions, Civil and Political Rights, Including the Questions of Disappearances and Summary Executions, Human Rights Council, paras. 18-19, U.N. Doc. A/HRC/4/20 (Jan. 29, 2007) (by Philip Alston) [hereinafter U.N. Doc. A/HRC/4/20]; Special Rapporteur on Extrajudicial, Summary or Arbitrary Executions, Addendum: Mission to the United States of America, Human Rights Council, paras. 71-73, 83, U.N. Doc. A/HRC/11/2/Add.5 (May 28, 2009) (by Philip Alston) [hereinafter U.N. Doc. A/HRC/11/2/Add.5]; Special Rapporteur on Extrajudicial, Summary or Arbitrary Executions, Addendum: Summary of Cases Transmitted to Government and Replies Received, Human Rights Council, 342-58, 358-61, U.N. Doc. A/HRC/4/20/Add.1, (Mar. 12, 2007) [hereinafter U.N. Doc. A/HRC/4/20/Add.1]; Special Rapporteur on Extrajudicial, Summary or Arbitrary Executions, Civil and Political Rights, Including the Question of Disappearances and Summary Executions, Addendum: Summary of Cases Transmitted to Governments and Replies Received, Comm'n on Human Rights, 264-65, U.N. Doc. E/CN.4/2006/53/Add.1 (Mar. 27, 2006) (by Philip Alston) [hereinafter U.N. Doc. E/CN.4/2006/53/Add.1]. In situations that do not involve the conduct of hostilities, where law enforcement operations during NIAC can be supported, the lex generalis of human rights law would apply. See Michael N. Schmitt ET AL., The Manual on The Law Of Non-International ARmed Conflict: With Commentary $§ 1.2$ (2006) [hereinafter The Manual on the LaW of Non-International Armed Conflict].

30. See generally Narrative of Dehumanization, supra note 8 (discussing post-9/11 evolution of law towards a more security-centric and a less individual liberty based jurisprudence). 
existing operational variant are inconsistent with international law, and thus, we may not proceed any further. However, identifying the former has the danger of further propelling international law towards a state-hijacked unregulated space. This is an eventuality we must avoid at all cost.

One difficulty in encapsulating targeted killing within international law comes from its temporal divergence with customary international law. Customary international law is a product of legal philosophies which emerged in response to the hostilities framework of an earlier era. ${ }^{31}$ Targeted killing on the other hand, is a product of modern innovationcharacterized by technological sophistication and structural asymmetry between the actors involved. Thus, fundamental questions must be asked of this divergence. Has maturation of The Hague and Geneva streams of law kept pace with the post-modern technological infusion in hostilities? Can the existing law overcome the accountability gap created by the long simmering asymmetric warfare? Must we attempt to expand the framework appropriately? This Article strives to answers these questions.

Placing targeted killing in an appropriate rights dimension will require teasing out all relevant technical components, for which there are fundamental roadblocks. Even before 9/11, right to life analysis was subsumed and apparently lost within the intersecting statutes of IHL and HRL. $^{32}$ Since 9/11, a severely flawed apocalyptic apprehension has engulfed people's constructs to such an alarming extent that, often times, even the killing of innocent children is being justified under exigencies of self-defense. ${ }^{33}$ Introduction of a rights dimension could lift the fog from people's minds by appropriately illuminating the discussion of targeted killing based on law's legitimacy. ${ }^{34}$ However, framing the appropriate rights

31. Customary International Law - Introduction, PEACE PALACE LIBRARY, http://www.peacepalacelibrary.nl/research-guides/public-international-law/customaryinternational-law/ (last visited May 5, 2014, archived at http://perma.cc/86UR-KZYE).

32. See e.g., Alexander Orakhelashvili, The Interaction between Human Rights and Humanitarian Law: Fragmentation, Conflict, Parallelism, or Convergence?, 19 EuR. J. OF INT'L L. 168 (2008) (arguing that although HRL does not guarantee an absolute right to life, protection against arbitrary deprivation of life during armed conflicts can be secured by extracting applicable restrictive covenants within IHL).

33. See Greenwald, supra note 7 (examining the mindset that gave rise to the justification principle of "we have to kill their children in order to protect our children.").

34. The principle of military necessity indicates that there must be some military advantage that could be gained from the attack. The Nuremberg Tribunal defines "military necessity" as:

Military necessity permits a belligerent, subject to the laws of war, to apply any amount and kind of force to compel the complete submission of the enemy with the least possible expenditure of time, life, and money.... It permits the destruction of life of armed enemies and other persons whose destruction is incidentally unavoidable by the armed conflicts of the war; it allows the capturing of armed enemies and others of peculiar danger, but does not permit the killing of innocent inhabitants for purposes of revenge or the 
dimensions is both complex and difficult, for reasons I list below.

First, a rights dimension needs a paradigmatic framework to evolve within in order to adequately illuminate conceptualization of relevant rights. Existing frameworks could partially address elements of targeted killing, but leave us to contemplate law's reach within a more comprehensive framework. Second, relevant state actors' reluctance in adopting a normative targeted killing framework is forcing the development of customary international law, based mostly on the reactive instantiation of isolated elements of law. This has the untenable legal consequence of conflating customary international law with biased state mandate, such as, manufacturing legal support for extrajudicial killing of terrorists. ${ }^{35}$ Such development has further decoupled the emerging targeted killing legal framework from the enduring principles of necessity, proportionality, distinction, and humanity. ${ }^{36}$ On the contrary, these principles are the set of foundational pillars of international law that my analysis below will benefit form.

Thus, this Article examines how the lack of accountability in the current targeted killing framework presents a fundamental dilemma of enforcement in IHL's modern applicability. Even though the complementarity between HRL and IHL provides enhanced protection of civilians in some situations, "accountability gaps" 37 and absence of granularity in identifying "legitimate targets" $" 38$ would make a legal case for

satisfaction of a lust to kill. The destruction of property to be lawful must be imperatively demanded by the necessities of war. Destruction as an end in itself is a violation of international law. There must be some reasonable connection between the destruction of property and the overcoming of the enemy forces.

Jefferson D. Reynolds, Collateral Damage On the 21st Century Battlefield: Enemy Exploitation of the Law of Armed Conflict, and the Struggle For a Moral High Ground, 56 A.F. L. REV. 1, 15-16 (2005) (alteration added), archived at http://perma.cc/XJJ3-FYCT; see also Michael N. Schmitt, The Principle of Discrimination in 21st Century Warfare, 2 YALE HuM. RTS. \& DEV. L.J. 143, 148-49 (1999).

35. See Guiora, supra note 19.

36. See Saby Ghoshray, When Does Collateral Damage Rise To The Level of a War Crime?: Expanding The Adequacy Of Laws Of War Against Contemporary Human Rights Discourse, 41 Creighton L. Rev. 679, 690 (2008) [hereinafter Collateral Damage ]. I argued that, while much scholarship analyzes the three pillars of proportionality, necessity, and distinction, often times, scholarship falls short of incorporating its fourth dimension of humanity, thus rendering it to be a vanishing pillar of international law. Id. However, some scholars have contributed to a much-needed discussion on humanity. See Theodor Meron, The Humanization of Humanitarian Law, 94 AM. J. INT'L. L. 239, 239 (2000); Michael Bothe, War crimes, in The Rome Statute of the International Criminal Court: A Commentary. Vol. 1, 379, 423 (A. Cassese et al. eds., Oxford Univ. Press 2002); see also Unlawful Killing with Combat Drones, supra note 23, at 24 ("[T] he principles of military necessity and of humanity are unlikely to restrict the use of force against legitimate military targets.") (alteration added).

37. See, Collateral Damage, supra note 36, at 689.

38. See, Collateral Damage, supra note 36, at 685-86. 
targeted killing difficult. Similarly, IHL's assertion of lex specialis rule and HRL's dependence on the relationship between individual and a "controlling state" ${ }^{39}$ would make the applicability of HRL in cases of targeted killing via drones problematic. This is more prevalent when drone strikes continue to kill innocent civilians. Similarly, IHL's assertion of lex specialis rule does not provide any additional opening for legitimizing targeted killing. Rather, the mounting civilian casualties in this new warfare paradigm $^{40}$ compel us to re-examine the key principles of IHL: the principle of distinction, the principle of proportionality, and the principle of military necessity.

Therefore, this Article proceeds in three steps. First, following some of the expanded definitions on the three principles of distinction, proportionality, and military necessity established in my earlier work, ${ }^{41}$ the current analysis revitalizes these key humanitarian law principles by providing a more interpretive gloss on their applicability in technology enhanced asymmetric warfare. Second, considering the ever-expanding list of participants in today's asymmetric warfare, the Article examines the emerging applicability of "legitimate target," 42 which allows for a more principled answer to the rhetorical question of whether an Al-Qaeda leader has the right to attend a wedding at night without dying. ${ }^{43}$ Third, the development of these first two segments allows for commenting on the continued relevance of the critical principles of IHL in protecting the core human rights values of The Hague and Geneva streams of law. In summary, this Article examines the legitimacy of targeting via drones by following the theoretical constructs of the scope and jurisdiction developed in my earlier work. ${ }^{44}$

Moving forward in this Article, Part II places the rights discussion within the proper context while questioning the legitimacy of the existing targeted killing framework of the combatants. Part III reexamines, revitalizes, and discusses the continued relevance of the principles of distinction, proportionality, and necessity for applicability in targeted killing within the context of IHL. Discussion of targeted killing's IHL

39. See Noam Lubell, Human Rights Obligations in Military Occupation, 94 INT'L REV. OF THE RED CROSS 317 (2012), archived at http://perma.cc/4NRJ-H9FZ.

40. See Living Under Drones, supra note 13, at 62 n.330 (citing field research to show escalating incidents of civilian casualties in drone strikes).

41. See generally Collateral Damage, supra note 36 (proposing a set of expanded interpretations of the three foundational pillars of the laws of war in light of escalations in asymmetric warfare).

42. Collateral Damage, supra note 36, at 694 (discussing who can be legally targeted).

43. A reexamination of "legitimate target" would adequately respond to this hypothetical wedding question by carefully categorizing who can be lawfully targeted and under what circumstances. See sources cited infra note 46 (providing a discussion of targeting outside of the zone of hostilities).

44. See Collateral Damage, supra note 36, at 686. 
applicability will lead to the continued analysis in Part IV, which examines whether this practice can be validated under IHL law. By introducing newer considerations that have not been discussed in detail, Part $\mathrm{V}$ addresses the need to consider whether the evolving paradigm can locate the right to targeted killing within the epistemology of international law. Finally, Part VI concludes by noting that the right to targeted killing mostly does not arrive by accidents of international events, and rather, must have a fundamental basis located within the human rights dimension of international law.

\section{THE RIGHT TO TARGETED KILLING: CONTROLLING SCENARIOS}

A significant precondition for legitimizing a right to targeted killing would be that all available legal parameters controlling the act are adequately identified and understood. From a normative framework, targeted killing without due process is in violation of the sanctity of human life. Thus, a discussion of targeted killing must accompany a rigorous theoretical analysis delineating the panoply of controlling scenarios where laws governing such killing must evolve with stringent preconditions attached to the act. Consequently, the legal parameters for targeted killing have to be identified along distinctly applicable categories, as I highlight below.

\section{A. Categorizing the Target}

The first category involves whether the target is within a geographical boundary of active hostilities. This category of targets can be further decomposed into two separate subgroups based on the nature of hostilities as defined in (i) the non-international armed conflict ("NIAC"); and (ii) the international armed conflict ("IAC"). ${ }^{45}$

45. See generally Int'l COMm. of The Red Cross, How Is The Term “ARmed COnflict" Defined In International Humanitarian Law? (2008), [hereinafter ICRC OPINION PAPER] archived at http://perma.cc/T72K-FQB6 (discussing the differences between NIAC and IAC. Within HRL, two types of armed conflicts are generally recognized, IAC, having at least two States on opposing sides of each other, and NIAC, where there may be one State pitted against non-State actors or non-governmental armed groups, or between non-State actors only. HRL treaty law is instrumental in distinguishing between IAC and NIAC within the meaning of Common Article 3 of the Geneva Conventions of 1949. In addition, NIAC can be governed by the definition provided in Article 1 of AP II. Statutes and international jurisprudence may not recognize any other type of armed conflict. However, opinions vary as to the various types of NIAC that may be recognized, the details of which are outside the scope of this discussion. In the context of HRL treaty, Common Article 2 to the Geneva Conventions of 1949 states that:

In addition to the provisions which shall be implemented in peace-time, the present Convention shall apply to all cases of declared war or of any other armed conflict which may arise between two or more of the High Contracting 
Parties, even if the State of war is not recognized by one of them. The Convention shall also apply to all cases of partial or total occupation of the territory of a High Contracting Party, even if the said occupation meets with no armed resistance.

Geneva Convention (IV) Relative to the Protection of Civilian Persons in Time of War art. 3.1, Aug. 12, 1949, 6 UST. 3516, 75 U.N.T.S. 287 [hereinafter Convention IV]. This would therefore entail, that IACs by definition may be opposed to "High Contracting Parties," or States, opening up the possibilities of NIAC to be triggered in most situations. Reading into the meaning of Common Article 2, author Schindler notes, "the existence of an armed conflict within the meaning of Article 2 common to the Geneva Conventions can always be assumed when parts of the armed forces of two States clash with each other. [ . . . ] Any kind of use of arms between two States brings the Conventions into effect." See ICRC OpINION PAPER, supra at 2 (alteration added); see also D. SCHINDLER, THE DifFERENT TyPeS OF Armed Conflicts ACCording to the Geneva Conventions AND Protocols 131 RCADI, Vol. 163 (1979-II). According to the ICRC:

An international armed conflict occurs when one or more States have recourse to armed force against another State, regardless of the reasons or the intensity of this confrontation .... The existence of an international armed conflict, and as a consequence, the possibility to apply International Humanitarian Law to this situation, depends on what actually happens on the ground. It is based on factual conditions. For example, there may be an international armed conflict, even though one of the belligerents does not recognize the government of the adverse party.

ICRC OPINION PAPER, supra at 1 (alteration added); see also Joint Services Regulations (ZDv) 15/2 of the German Army, in The Handbook of Humanitarian Law In ARmed Conflicts 527-28 (Dieter Fleck, ed., Oxford Univ. Press 1995). The Commentary of the Geneva Conventions of 1949 observes:

[A]ny difference arising between two States and leading to the intervention of members of the armed forces is an armed conflict within the meaning of Article 2, even if one of the Parties denies the existence of a state of war. It makes no difference how long the conflict lasts, or how much slaughter takes place.

Geneva Convention (II) for the Amelioration of the Condition of the Wounded and Sick in the Armed Forces in the Field, Aug. 12, 1949, 6 UST. 3114, 75 U.N.T.S. 31 [hereinafter Convention II]; see also COMMENTARY ON THE GENEVA CONVENTION FOR THE Amelioration of the CONDition of THE Wounded AND Sick IN ARMEd Forces in the Field 32 (Jean S. Pictet ed., 1952) [hereinafter CommentARY ON THE GENEVA CONVENTION]. Similarly AP I's art. 1, para. 4 observes that:

[S]ituations referred to in [Article 2] include armed conflicts in which peoples are fighting against colonial domination and alien occupation and against racist regimes in the exercise of their right of self determination, as enshrined in the Charter of the United Nations and the Declaration on Principles of International Law concerning Friendly Relations and Co-operation among States in accordance with the Charter of the United Nations.

Protocol Additional to the Geneva Conventions of August 12, 1949, and Relating to the Protection of Victims of International Armed Conflicts (Protocol 1), Jun. 8, 1977, 1125 U.N.T.S. 3 (alterations added) [hereinafter AP I]. Commenting on when IAC triggers, H.P. Gasser explains that:

[A]ny use of armed force by one State against the territory of another, triggers the applicability of the Geneva Conventions between the two States . . . It is also of no concern whether or not the party attacked resists .... [A]s soon as the armed forces of one State find themselves with wounded or surrendering 
The second category involves a target residing outside of active hostilities, for which any act of targeted killing has to be conducted from a remote location. ${ }^{46}$ Despite having some characteristics of the IAC framework, targeted killing under this category is problematic on two specific grounds. First, the geographical remoteness between the targeting

members of the armed forces or civilians of another State on their hands, as soon as they detain prisoners or have actual control over a part of the territory of the enemy State, then they must comply with the relevant convention.

H.P. Gasser, International Humanitarian Law: An Introduction, in HuMANITY FOR AlL: THE InTERnAtional Red Cross AND Red CREsCEnt Movement, 510-11 (H. Haug ed., 1993) (alterations added).

46. In this context, there are two clear issues: first, the issue is that of targetingreferring to striking individuals outside the zone of hostilities. The second is that of command and control-referring to executing strikes from thousands of miles away. If the legality of the first is the center of immense debate, the second should clearly be illegal under international law, as I have discussed in this Article. The US' adoption of targeted killing of suspected terrorists from remote locations is well documented. See AP, US Kills Al-Qaeda Suspects in Yemen, USA TODAY, (Nov. 5, 2002, 7:14 AM), http://usatoday30.usatoday.com/news/world/2002-11-04-yemen-explosion_x.htm, archived at http://perma.cc/7YXN-6CYD; See also Doyle McManus, A US License to Kill, L.A. TIMES (Jan. 11, 2003), http://articles.latimes.com/2003/jan/11/world/fg-predator11, archived at http://perma.cc/J8V6-ZV5S (stating the US government maintains that its actions were appropriate under the international law of armed conflict and that the Commission and its special procedures have no mandate to address the matter); Michael J. Dennis, Human Rights in 2002: The Annual Sessions of the UN Commission on Human Rights and the Economic and Social Council, 97 AM. J. INT'L L. 364, 367, n.17 (2003). Although opinions about the legality of military strikes outside of hostilities differ, I concur with scholars who view this type of actions as unlawful. See generally Mary Ellen O'Connell, Lawful Use of Combat Drones, Congress of the United States House of Representatives Subcommittee on National Security and Foreign Affairs Hearing: Rise of the Drones II: Examining the Legality of Unmanned Targeting, Apr. 28, 2010, archived at http://perma.cc/YWA9-VGKG (presenting a set of restrictive covenants that may eliminate perceived conditions for denial of rights). With respect to the second issue, it has been established that military drones are being remotely controlled from within the US for striking in Pakistan. As documented by Jane Mayer:

The US government runs two drone programs. The military's version, which is publicly acknowledged, operates in the recognized war zones of Afghanistan and Iraq, and targets enemies of US troops stationed there. As such, it is an extension of conventional warfare. The C.I.A.'s program is aimed at terror suspects around the world, including in countries where US troops are not based.... The program is classified as covert, and the intelligence agency declines to provide any information to the public about where it operates, how it selects targets, who is in charge, or how many people have been killed.

Jane Mayer, The Predator War, THE New Yorker, Oct. 26, 2009, http://www.newyorker.com/reporting/2009/10/26/091026fa_fact_mayer, archived at http://perma.cc/3B7G-BZBK (alteration added). As incredible as it sounds, some drones are being remotely operated from as far as the US State of Nevada. See Peter Bergen \& Katherine Tiedemann, The Drone War, New AmERicA Foundation, Jun. 3, 2009, http://www.newamerica.net/publications/articles/2009/drone_war_13672, archived at http://perma.cc/M6QE-XNPT. 
actor and the target might require encroachment of a third-party's physical space. This calls for a legal determination to ensure the targeting does not violate the territorial sovereignty during the act of killing. ${ }^{47}$ Second, prior to killing, the targeting actor must identify whether the target has ceased to become part of active hostilities. Once adequate due diligence determines an act is not an active hostility, the act in question must go through the rigors of the law enforcement framework, which provides a much higher threshold for legitimizing extrajudicial acts of violence. ${ }^{48}$

Technological superiority of the targeting actors in today's asymmetric warfare has promoted the rise of a third category of targets. From a targeting perspective, the physical locations of these targets change over time, from inside the hostilities, to proximately near the hostilities, to outside the hostilities. Thus, the identification of the legitimate target becomes very difficult, which makes legal determination even more puzzling. The availability of such a wide range of targets, therefore, calls for establishing a legal framework to define the individual profile of who could be a legitimate target under international law.

\section{B. Profiling the Target}

Legitimizing an individual as a target for assassination is based on accepting any one of the three categories identified above. The post-9/11 legal analysis has extensively used "enemy combatant" 49 as the prototypical

47. See Bergen \& Tiedemann, supra note 46 (noting that the operators of drones may be geographically isolated while striking individuals from these remote locations, the actual strikes are taking place in a physical space, causing territorial violation of geographical border).

48. The legal community has been divided since $9 / 11$ as to the efficacy of the antiterrorism model, as the debate centers around "law enforcement mechanism" vs. "military justice." Some commentators suggest that adherence to the accepted rule of law and law enforcement methods may have better results against terrorism. See, e.g., SETH G. JONES \& Martin C. Libicki, How Terrorist Groups End: Lessons For Countering Al QA'IDA (2008), archived at http://perma.cc/SR3D-2QLC. In an earlier work, I presented the difference between the two models and examined their appropriateness in various cases. See Paradigm of Indefinite Detention, supra note 26 (delineating between the laws of war model and its law enforcement counterpart to tease out the shaping effect of $9 / 11$ in dealing with alleged terrorists).

49. Immediately after $9 / 11$, the United States Administration coined the term "enemy combatant" to broadly categorize individuals detained by the US military and its allied forces in its global initiative on terrorism. This term included those who have the maximum likelihood of being tried under the rules of military tribunal or any individuals that the United States government deemed to be members of Al-Qaeda or the Taliban, or to be participants in armed conflict against the United States. See generally Guantanamo Bay: Military Commissions and Enemy Combatants, JURIST, http://jurist.org/feature/2013/07/guantanamo-bay-militarycommissions-and-enemy-combatants.php, archived at http://perma.cc/CKZ4-LSAN. The original idea was driven by the assumption that, once the designation of "enemy combatant" is assigned to a person, he or she could be detained indefinitely and would have no right under the 
model for targeting individuals for extrajudicial detentions and assassinations. I have analyzed this model's deficiency both in the context of detention and extrajudicial killing elsewhere. ${ }^{50}$ More importantly, the enemy combatant model is problematic within the context of targeted killing, especially within the non-hostile and hybrid hostilities paradigms. To overcome this difficulty, some commentators have used the term "functional combatant,"

laws and customs of war or the Constitution to meet with counsel regarding detention or to understand the charges against the individual. Id.; see also William Haynes, Gen. Counsel of the Dep't of Def., Enemy Combatants, Council on Foreign Relations (Dec.12, 2002), $\mathrm{http} / / / \mathrm{www} . c f r . o r g /$ international-law/enemy-combatants/p5312, archived at http://perma.cc/FPW5-HAPM. This is in violation of the IHL under the guidelines provided in the four Geneva Conventions of 1949. See generally Geneva Convention (III) Relative to the Treatment of Prisoners of War, Aug. 12, 1949, 6 UST. 3316, 75 U.N.T.S. 135 [hereinafter Convention III] (outlining the permissible conditions and allowable treatments of prisoners); Protocol Additional to the Geneva Conventions of 12 August 1949, and Relating to the Protection of Victims of Non-International Armed Conflicts (Protocol II), Dec. 7,1978, 1125 U.N.T.S. 609 [hereinafter AP II] (outlining the essential rule of the law of armed conflict to wars inside a country or sovereign territory); Convention II, supra note 45; Convention IV, supra note 45; AP I, supra note 45. The detainees of the war in Afghanistan have the legitimate right to POW status accorded to them under the Third Geneva Convention. "[POWs] ... are ... [m]embers of the armed forces of a Party to the conflict... [who have] fallen into the power of the enemy." Convention III, supra, arts. 4.A(1)-(5) (alterations added). "Prisoners of war shall be released and repatriated without delay after the cessation of active hostilities." Id. art. 118. Clearly, the terminology "enemy combatant" does not have support in the corpus of laws that illuminate laws of war or HRL, as scholars and activists repeatedly question the legitimacy of applying the terminology to deny prisoners of wars status to the Taliban members who were captured in the battlefield in Afghanistan. "The Bush Administration has used the term 'unlawful combatant' or 'enemy combatant' interchangeably [and with effective use] to stress that the detainees are not considered POWs." See Saby Ghoshray, Hamdan's Illumination Of Article III Jurisprudence In The Wake of The War on Terror, 53 WAYNE L. REv. 991, 1011, n. 84 (2007) [hereinafter Hamdan's Illumination of Article $I I I$. However, the Administration, in its zeal to combat terrorism, has failed to comply with its obligation under customary international law to make a clear distinction between combatants and noncombatants. As a result, many civilian noncombatants were captured and detained as enemy combatants, which has been documented heavily in the literature, and I shall refrain from readdressing them here.

50. See generally Saby Ghoshray, On the Judicial Treatment of Guantánamo Detainees in International Law, in ClARK Butler, GuANTÁNAMO BAY AND THE JUdiCIAL-Moral Treatment Of The Other 80, 85-86 (Purdue Univ. Press 2006) [hereinafter On the Judicial Treatment of Guantánamo Detainees].

51. As the usage of "enemy combatant" has become legally burdensome for states involved in indefinite detention and targeted killing, the term "functional combatant" has entered the legal vernacular to read a broader meaning into combat related role for suspected terrorists. Invocation of such term, in my view, advances a broader right to kill, by incorporating a wide range of functionalities into the role of a combatant. See generally Robert Chesney, Who May Be Killed? Anwar al-Awlaki as a Case Study in the International Legal Regulation of Lethal Force, in 13 Y.B. OF INT'L HuM. L. 3 (2010), available at http://papers.ssrn.com/sol3/papers.cfm?abstract_id=1754223 (explaining how the article 51 right to self-defense can be invoked in justifying the killing of Anwar al-Awlaki, an American citizen without due process of law). 
expand the meaning of "functional." This definitional flaw comes from its inability to adequately distinguish between civilians and combatants - an area that must be elaborated on for a better appreciation of its nuances. Understanding the implication of using the term functional combatant for targeted killing analysis, therefore, would require identifying the applicable assumptions and the limiting cases. Next, I embark on such an analysis to examine the profile of a functional combatant in appropriate detail.

Who is a functional combatant? For the purpose of our current inquiry, could such an individual, if not actively engaged in hostilities, be targeted for killing? When there is no publicly available information about an individual, how can the legal community ensure that individuals are not being randomly targeted for killing? ${ }^{52}$ These are some of the poignant issues that must be brought to the forefront. Therefore, the right to targeted killing must be premised on recognizing targeted killing as an act that flows from rights under international law. In order to place such rights within an appropriate epistemological dimension of law, ${ }^{53}$ the act must be scoped,

52. See Death from Above, supra note 14. The authors estimate that between 2006 and 2009 (data up to first quarter), 700 persons died in attacks killing 14 intended targets. Death from Above, supra note 14. Peter Bergen and Katherine Tiedemann have found similar ratios of intended to unintended victim: "Since 2006, our analysis indicates, 82 US drone attacks in Pakistan have killed between 750 and 1000 people. Among them were about 20 leaders of al Qaeda, the Taliban, and allied groups, all of whom have been killed since January 2008." Peter Bergen \& Katherine Tiedemann, Voices for Creative Nonviolence, Revenge of THE DRONES (2009), archived at http://perma.cc/4GQX-V76L. The United States government, however, does not provide official data on this. However, some websites do provide such information. See generally Peter Bergen \& Katherine Tiedemann, The Year of the Drone, New AMERICA Foundation (Feb. 24, 2010), http://www.newamerica.net/sites/newamerica.net/files/policydocs/bergentiedemann2.pdf, archived at http://perma.cc/XSE6-SWPR (tracking strikes in Pakistan).

53. Drawing from the methodologies used in complexity analysis, I have introduced the concept of ontological and epistemological dimension in discussing "rights paradigm." See Ghoshray, Narrative of Dehumanization, supra note 8. This theory was introduced and popularized in the 1970s to understand complex paradigms in organizational or social framework. Ontological and epistemological constructs were created by social scientists. See generally Gibson Burrell \& Gareth Morgan, Sociological Paradigms And Organisational ANAlysis: ElEments of the SOCIOlOGy of Corporate Life (Heinemann Educational Books 1979); NoRman BlaikIE, ApProAChes To SOCIAL InQuiRY 25 (Polity Press 2007). The concept of epistemology and its ontological counterparts were known in the early times of Plato. See generally Phil Johnson \&. Catherine Cassell, Epistemology and Work Psychology: New Agendas 74 J. Occupational \& Org. Psychol. 125, 125 (2001) (highlighting the importance of epistemology in dissecting inferences drawn from psychological evaluations). Despite, the long histories of these methodologies for the construction of social realities, awareness of their clear distinctions were only recently made clear. See generally Dennis Gioia, Give It Up: Reflections on the Interpreted World, 12 J OF MGMT. INQUIRY 285, 285 (2003) (observing ontology as a relationship between the observer and the nature of the social phenomenon being observed, while noting epistemology as the mechanism through which to conceptualize such phenomenon). Given the complexity of the rights narrative, it is important to construe a proper epistemology of a phenomenon's full 
defined, and defended within law.

Right to targeted killing requires legitimizing a series of antecedent acts that form the basis of such extrajudicial killing. In this context, the relevant legal paradigm is still in a maturation process, which makes it difficult to fully appreciate or endorse such rights appropriately. This is because an act within the context of international law should flow naturally from a legally developed right that may have either sprung up as a fundamental force or have been derived from explicit mandates of international law. To find this mandate we must examine separately the strands that collectively comprise international law. These three strands include: (1) IHL - acting alone as a self-sustaining legal framework; (2) HRL - acting alone in a self-sufficient capacity; and (3) the evolving legal paradigm post-9/11, either working outside the IHL-HRL dyad or working interactively and complementarily with the dyad.

\section{IS TARGETED KILLING SUPPORTABLE UNDER INTERNATIONAL HUMANITARIAN LAW ALONE?}

Can a functional combatant identified above be killed within the framework of targeted killing? To adequately respond to this, the constructed profile must be tested for its IHL's applicability. An assessment is required on the nature of the conflict to determine where the related hostility in question should fall, given the binary choice between the NIAC $^{54}$ paradigm and its IAC counterpart. ${ }^{55}$ Common Article 2 of the Geneva Convention governs the scope and conduct of hostilities under IAC. ${ }^{56}$ On the other hand, Common Article 3 governs the scope and

scope, evolution, and future trajectory. We can construe ontological dimension as the set of dimensions that allows us to understand the nature of a phenomena, whereas, epistemology is the dimension through which we perceive that phenomena. In this sense, according to the scholars mentioned above, both ontological and epistemological assumptions give us the meaning that something can be described in accordance with what someone believes about the state of that complex framework, such that the reality of that phenomenon is understood from a mediated social interpretation. The concept of ontological dimensions brought to distinguish between human cognitive experience of social and natural reality and its independent existence prior to that cognition. More specifically, where ontology provides us with the vehicle through which to construe independent existence, decoupled from cognitive bias, epistemology alerts us to the causal relationships amongst variables such that our reality is constructed outside of the individual through the multitude of sensory stimuli that shapes our experience. According to Gioia, "The reality people confront is the reality they construe." Id. at 287. For a detailed discussion of rights narrative in international law within the context of war on terror consider an earlier work of mine. See Ghoshray, Narrative of Dehumanization, supra note 8.

54. See ICRC OpINION PAPER, supra note 45 (discussing NIAC in general, and the types of NIAC which may be recognized under statutes and international jurisprudence).

55. See ICRC OPINION PAPER, supra note 45 (noting that an IAC occurs when one or more states have recourse to armed force against another state).

56. See Convention IV, supra note 45, art. 2 (stating that the Convention applies to 
conduct of NIAC ${ }^{57}$ Yet, difficulties might arise in categorizing a conflict when parties do not follow the norm. For example, if one of the state parties in armed conflict either does not explicitly accept or implicitly denies occurrence of such a conflict, we might be left with resorting to interpretation based on emerging case laws. In this regard, the expanded

armed conflict which may arise between two or more parties).

57. Emerging consensus in jurisprudence suggests, in the context of NIAC, Common Article 3 to the Geneva Conventions of 1949 should be considered the governing law. See Ghoshray, Hamdan's Illumination of Article III Jurisprudence in the Wake of The War on Terror, supra note 49 (charting the trajectory of Hamdan Court's broader observations related to Common Article 3's applicability on NIACs). However, in the absence of a legally binding HRL definition of Common Article 3, it may be incumbent upon us to review the facts surrounding a specific scenario, for a determination of its applicability. In this regard, a given situation can be analyzed within the framework developed based on state practices and case laws. The dual imposition of state practices and case laws is noteworthy here, because lacking a force of applicability from treaty obligations, case laws could become obligatory in force. Recent case laws brought forth important elements into the evolving definition of an armed conflict in the context of NIAC within the meaning of Common Article 3, which do not find explicit textual reference, but must therefore be implicitly acquired in meaning. See Prosecutor v. Tadic, Case No. IT-94-I-T, Opinion and Judgment, paras. 561-68 (Int'l Crim. Trib. for the Former Yugoslavia May 7, 1997) [hereinafter Tadic Judgment] (discussing the protracted armed violence between governmental forces and organized armed groups); see also Prosecutor v. Limaj, Case No. IT-03-66-T, Judgment, paras. 84, 135-70, (Int'l Crim. Trib. for the Former Yugoslavia Nov. 30, 2005) [hereinafter Fatmir Judgment] (observing that, first, the hostilities must reach a minimum level of intensity, as it defines a minimum threshold level during when the hostilities have a collective character or, when a government is compelled to use military force against the opposition). Thus, judgments and decisions of the ICTY further elaborate on applicable definitions of NIAC. In the context of NIAC, ICTY judgment supports characterizing prolonged armed violence between governmental authorities and organized armed entity, or that between organized armed groups within a state as armed conflict. Tadic Judgment, supra, para. 628. The ICRC opinion supports this view, "Common Article 3 applies to 'armed conflicts not of an international character occurring in the territory of one of the High Contracting Parties.'” ICRC OPINION PAPER, supra note 45 , at 3 . It therefore can be interpreted that, when there is armed conflicts in which one or more non-governmental armed group is involved or, armed conflicts between governmental armed forces and non-governmental armed groups, or between such groups, the hostilities would be covered under NIAC. ICRC further notes that, since the universal ratification of the four Geneva Conventions, the requirement of armed conflict occurring "in the territory of one of the High Contracting Parties" may have lost its practical significance. ICRC OPINION PAPER, supra note 45, at 3. Moreover, in my view, given the escalating number of asymmetric wars taking place globally, we must infer that, any armed conflict between State and non-State actors indeed must take place on the territory of one of the Parties to the Convention. This would also imply that in order to distinguish an armed conflict, in the meaning of Common Article 3, from less serious forms of violence, such as internal disturbances and tensions, riots or acts of banditry, the situation must reach a certain threshold of confrontation. See SCHINDLER, supra note 45, at 147. (identifying various instances of NIAC under Common Article 3); see also Jelena Pejic, The Protective Scope of Common Article 3: More Than Meets the Eye, 93:881 InT'L REV. OF THE RED Cross 189, 193-95 (2011), archived at http://perma.cc/59F7-JXCY (arguing that Common Article 3 to the Geneva Conventions may be given an expanded geographical reading as a matter of treaty law). 
reading of the 1949 Geneva Convention's "High Contracting Parties"58 has become the norm, most notably by virtue of the 1995 Tadic $^{59}$ case of the International Criminal Tribunal for the former Yugoslavia ("ICTY"). Contemporary application of the Common Article 2's protection paradigm will still encapsulate most instances of hostilities involving two state parties. This is regardless of whether or not the state parties are thrust into such conflict by intention or happenstance, and, whether or not all or parts of the state's armed forces take part in the hostilities. ${ }^{60}$ This protection paradigm also extends to a range of hostilities, including hors de combat, ${ }^{61}$ which poses a rather high threshold for a state willing to invoke a right to targeted killing. Having identified the distinction between NIAC and IAC, the following analysis will further clarify whether there can be a potential target for state sponsored killing under IHL.

\section{A. Exploring the Non-International Armed Conflict/International Armed Conflict Distinction}

Here, two points are noteworthy. First, IHL provides clear demarcation between IAC and NIAC by determining whether state parties are involved or not. ${ }^{62}$ Second, IAC provides a much higher threshold of protection for combatants, which flows from the full suite of Additional Protocols, including I (“AP I"), II (“AP II"), and III (“AP III"), in addition to the 1949 Geneva Conventions. ${ }^{63}$ Therefore, the first step toward legitimizing a potential target under IHL would be to explicitly categorize

58. See ICRC OPInION PAPER, supra note 45, at 1 (noting the 1949 Geneva Convention's discussion of the High Contracting Parties).

59. ICRC OPINION PAPER, supra note 45, at 2 (discussing the ICTY's definition of an armed conflict in the Tadic case).

60. ICRC OPINION PAPER, supra note 45, at 1-2 (noting that an IAC occurs, regardless of the reasons or intensity, when one or more states have armed recourse against another state).

61. See Int'l Comm. of the Red Cross, Customary IHL, Rule 47: Attacks against Persons Hors de Combat (2014), archived at http://perma.cc/N9VS-M87D (explaining the framework in which combatants are normally granted special protection under IHL, providing they do not take part in hostilities and as such remain "outside the fight.").

62. See ICRC OPINION PAPER, supra note 45 (discussing the governing doctrines for IACs and NIACs).

63. See AP I, supra note 45; AP II, supra note 49. The United States has not ratified these Protocols; however, many foreign countries recognize these Protocols as customary International Law. See Michael J. Matheson, The United States Position on the Customary International Law to the 1977 Protocols Additional to the 1949 Geneva Conventions, 2 AM. UNIV. INT'L L. REV. 415, 420 (1987) (identifying specific military conducts in the war zone that insulates military personnel from being charged with a war crime); see also Dietrich Schindler \& Jiři Toman, Protection of Civilian Populations Against the Dangers of Indiscriminate Warfare, in THE LAWS OF ARMED CONFLiCts 259 (Martinus Nijhoff Publishers 1965). 
the related hostility in either the IAC or the NIAC category. According to the Common Article 2, at least one of the parties from the two opposing sides must be a state, in which case, the IHL applicability might turn on the member state's treaty obligations. ${ }^{64}$ Therefore, it is important to isolate and distinguish the category of the hostilities.

Looking through the prism of continued hostilities post-9/11, the United States can be recognized as the designated state party and either AlQaeda $^{65}$ or Al-Qaeda in the Arabian Peninsula ${ }^{66}$ can be considered the opposing faction. Evaluating the given elements here, there is no legal basis to categorize the hostilities as IAC. Thus, targeted killing of a functional combatant within the context of IAC may not be legally justified. Once such legal combatant status review rejects targeted killing under IAC, ${ }^{67}$ analysis should default to a NIAC status review, which automatically triggers an evaluation based on provisions under the Common Article 3.

Warfare in the twenty-first century has been going through a metamorphosis. Manifested both in their asymmetric nature and increased participation by non-state actors, hostilities categorized under NIAC continue to increase in frequency. Therefore, the current inquiry to determine a target's justifiability under NIAC may be accomplished by proceeding along two specific lines of investigation. First, how much of an expanded reading of Common Article 3 is legally justifiable in instances involving non-state actors? Second, from where would the right to targeted

64. See ICRC OPINION PAPER supra note 45 (discussing armed conflicts including nongovernmental groups and state actors).

65. Al-Qaeda (AQ) is a loose conglomeration of global Islamist organization that is driven by Osama Bin Laden's ideology. Various articles and commentaries during the last decade have attempted to define and describe the ideology, objective and framework of Al-Qaeda. See Jason Burke, What Exactly Does al-Qaeda Want? THE GuARDiAn (Mar. 21, 2004 11:08 PM), $\mathrm{http} / / \mathrm{www}$.guardian.co.uk/world/2004/mar/21/alqaida.terrorism, archived at http://perma.cc/D5UZ-4LUM; Al-Qaida, GLOBALSECURITY, http://www.globalsecurity.org/ military/world/para/al-qaida.htm (last visited Oct. 28, 2013, archived at http://perma.cc/KWZ5JPV3); Andrew Wander, A History of Terror: Al-Qaeda 1988-2008, The GuARDian (Jul. 12, 2008), http://www.guardian.co.uk/world/2008/jul/13/ history.alqaida, archived at http://perma.cc/7PM4-8RX3; Yassin Musharbash, The Future of Terrorism: What al-Qaida Really Wants, SPIEGEN OnLINE (Aug. 12, 2005, 3:53 PM), http://www.spiegel.de/international/ the-future-of-terrorism-what-al-qaida-really-wants-a-369448.html, archived at http://perma.cc/87T8-J33A; see also Ghoshray, Narrative of Dehumanization, supra note 8, at $164-70$.

66. The branch of Al-Qaeda that is active in Arabian Peninsula, especially in Saudi Arabia and Yemen is abbreviated as AQAP in the contemporary discourse. See Jonathan Masters \& Zachary Laub, Al-Qaeda in the Arabian Peninsula (AQAP), COUNCIL ON ForeIGN RELATIONS (Aug. 22, 2013), http://www.cfr.org/yemen/al-qaeda-arabian-peninsulaaqap/p9369Cfr.org, archived at $\mathrm{http}: / /$ perma.cc/3HUS-2N4P.

67. See Pejic, supra note 57. Here I draw attention to the fact that, based on IAC's definition requiring "at least two [State] parties," a broader definition of combatant belonging to non-State actors may be rejected. 
killing flow in cases dealing with individuals already in enemy hands? In this context, an increase in the frequency of NIACs since 9/11 may provide the strongest rationale for bringing armed conflicts involving non-state actors within the framework of Common Article $3 .^{68}$ However, this will require setting up a basis for such categorization. Identifying the geographical context of the hostilities in question will be the first step in that direction.

Given that the majority of US acts of targeted killing have been concentrated in three specific regions-Afghanistan, Pakistan, and Yemen $^{69}$ - let us evaluate the status of a functional combatant under Common Article 3 by focusing on these theaters. In all three scenarios, the state actor, the United States, has officially declared war against either the members of Al-Qaeda ${ }^{70}$ or the members of Al-Qaeda in the Arabian Peninsula. ${ }^{71}$ While Al-Qaeda is operationally active in both Afghanistan and Pakistan, Al-Qaeda in the Arabian Peninsula is primarily active only in Yemen. ${ }^{72}$ However, for the purpose of legal determination, integrating facts on the ground with "treaty obligation" under Common Article 3 might render NIAC applicability problematic. ${ }^{73}$ This rejection of Common Article 3 would create an unregulated IHL space, creating temptation for some state actors to operate with impunity. Such an untenable scenario can be avoided by crafting a set of deterministic criteria based on expanded interpretation of IHL's legal and policy framework. This would then form the basis of support for a NIAC application of the hostilities in question.

Current jurisprudence assesses NIAC under two main criteria: intensity of violence ${ }^{74}$ and parties to the violence. First, it is incumbent upon us to carefully isolate and analyze all the elements of a conflict involving a non-state actor and to determine whether the threshold of intensity has met the requirements of NIAC within the meaning of Common

68. Pejic, supra note 57 (noting that in the context of NIAC, Common Article 3 should be considered governing law).

69. See Voices for Creative Nonviolence, supra note 52 (discussing targeted killings in Pakistan and other areas).

70. On September 21, 2001 President George Bush, "vowed the US would use all its resources to avenge the worst-ever attacks on American soil." 2001: US Declares War on Terror, BBC, http://news.bbc.co.uk/onthisday/hi/dates/stories/september/12/newsid_2515000/ 2515239.stm (last visited Nov. 26 2013, archived at http://perma.cc/EJP4-ERMW); See also Authorization for Use of Military Force, Pub. L. No. 107-40, 115 Stat. 224 (2001) [hereinafter AUMF].

71. The concern over AQAP is clear. As noted, "[w]hile core AQ remains a serious threat, I believe the most serious threat to the homeland today emanates from members of AQAP.” Mark F. Giuliano, The Post 9/11 FBI: The Bureau's Response to Evolving THREATS 2 (2011) (alteration added), archived at http://perma.cc/797T-FRVZ.

72. See id. (discussing threats from AQAP specific to Yemen).

73. See Pejic, supra note 57.

74. Pejic, supra note 57. 
Article $3 .^{75}$ In the absence of a legally binding IHL based definition, a higher threshold of intensity should generally be applied to distinguish NIAC from internal disturbances within a state. Despite powerful states not showing fidelity to this threshold rule, ${ }^{76}$ international judicial bodies strongly recommend adhering to such delimiting criteria in distinguishing between NIAC and IAC under the Common Article $3 .^{77}$ Measuring an appropriate threshold, however, may not be so straightforward from an implementation perspective.

How do we measure the threshold of intensity to ensure it has been elevated to the desired level? Jurisprudence ${ }^{78}$ identifies a number of factors as indicative characteristics to determine such a threshold. Without such a threshold, states could simply invoke NIAC for the purpose of targeted killing. Thus, one of the goals of such an assessment is to prevent the

75. Within the context of Common Article 3, armed hostilities, not every incident can rise to the level of NIAC, as jurisprudence has developed to guide us based on threshold of intensity. AP I to the Geneva Conventions set a higher threshold of applicability than Common Article 3, even though some would suggest that their scope of applicability should have been the same. Common Article 3's lack of treaty obligations provides a much restricted textual guidance under AP II, which is to be read as an armed conflict in which the non-State party must "exercise such control over a part of [the territory of a State party] as to enable [it] to carry out sustained and concerted military operations and to implement this Protocol." AP II, art. 2, supra note 49 (alteration added). This sets the scope of application of AP II on a much narrower threshold than that of Common Article 3, with Article 3 maintaining a separate legal significance even when AP II is also applicable. The relationship between applicable rules in this context comes from article 1.1 of AP II, pursuant to which the Protocol "develops and supplements Article 3 common to the Geneva Conventions of 12 August 1949 without modifying its existing conditions of application." Id. See Pejic, supra note 57, at 190, n.1 (arguing that Common Article 3 to the Geneva Conventions and AP II taken together may have provided a higher threshold of intensity, while identifying some specific criteria). Literature and case law further implies that assessments of NIAC, which turn on an examination of events on the ground, where indicative factors might include, the number: (1) duration and intensity of individual confrontations; (2) the type of weapons and other military equipment used; (3) the number and caliber of munitions fired; (4) the number of persons and types of forces partaking in the fighting; (5) the number of casualties; (6) the extent of material destruction; and (7) the number of civilians fleeing combat zones. See Fatmir Judgment, supra note 57, para. 90; Prosecutor v. Haradinaj, Case No. IT-04-84-T, Judgment, para. 84 (Int'l Crim. Trib. for the Former Yugoslavia Apr. 3, 2008) [hereinafter Haradinaj Judgment]; see also Tadic Judgment, supra note 57, para. 561. As I note in this Article, at the end of the day, final assessment is to be based on a case-by-case scenario analysis against the slew of indicative factors discussed here. See SchindLer, supra note 45; see generally Nils MElzer, TARGETED KILLING IN INTERNATIONAL LAW (2008).

76. See SCHINDLER, supra note 45, at 256 (presenting a more nuanced framework of hostilities that can account for emerging difficulties borne out of complexities of asymmetric warfare).

77. SCHINDLER, supra note 45 , at 256.

78. See Tadic Judgment, supra note 57, para. 561; see also Haradinaj Judgment, supra note 75 , para. 51 . 
inclusion of isolated and fragmented hostilities from coming under the purview of the Common Article 3 definition of NIAC. Thus, contradistinction must be made between NIAC and lower threshold hostility by reviewing a set of factors characterizing the nature, scope, duration, and sophistication of weaponry. ${ }^{79}$ In this evaluation, the humanitarian impact of the hostility must also be taken into account before identifying the conflict as NIAC for the purpose of IHL application. Application of a threshold test would be the most manageable way to determine the qualifying intensity under NIAC. Due to the multiple interacting factors that might shape the required threshold intensity, a general functional expression can be developed as an equation in the following:

Intensity $=f$ (duration, frequency of attacks, sophistication of weaponry, military nature, extent of civilian displacement, severity of victimization, territorial control issues).

This characterization, a mathematical equation, would be both robust and manageable. This framework would allow for all the necessary factors to be considered for a determination of whether the intensity of hostilities has risen to the occasion of NIAC under Common Article $3 .^{80}$

It is instructive to note that each of the indicative factors have been specifically addressed in the expanded reading of Common Article 3 application. For example, both the Tadic decision of the ICTY and the Statute of the International Criminal Court ("ICC") apply "protracted armed violence" or "protracted armed conflict" as a Common Article 3 trigger for NIAC. ${ }^{81}$ This has been further corroborated by a recent ICRC position paper. $^{82}$ According to this position paper, IHL applicability of NIAC is triggered in situations where:

Protracted armed confrontations are occurring between governmental armed forces and the forces of one or more armed groups, or between such groups arising on the territory of a State [party to the Geneva Conventions]. The armed confrontation must reach a minimum level of intensity and the parties involved in the conflict must show a minimum of [organization.$^{83}$

This ICRC observation not only presents a strong rejoinder against

79. See Tadic Judgment, supra note 57.

80. See Voices for Creative Nonviolence, supra note 52 (discussing the intensity of hostilities necessary under NIAC).

81. See Tadic Judgment, supra note 57, para. 561.

82. See ICRC OPINION PAPER, supra note 45 , at 4.

83. ICRC OPINION PAPER, supra note 45 , at 5. 
rejection of Common Article 3's applicability for NIAC under the "intensity of violence" criteria ${ }^{84}$ but also supports applicability under the second criteria of "parties to armed conflict." ${ }^{85}$ While the state party in the present case is conspicuous by its ability to engage in targeted killing, a question arises whether Al-Qaeda or Al-Qaeda in the Arabian Peninsula constitutes the second "party" to the precondition of "at least two parties." Indicative factors of organizational capability of these groups have been well studied. By assessing their command, control, and planning capabilities, ${ }^{87}$ scholars agree that these groups meet the criteria for NIAC. ${ }^{88}$ As observed in my earlier work, ${ }^{89}$ the US Supreme Court in Hamdan $v$. Rumsfeld, noted that the conflict with Al-Qaeda satisfies the Common Article 3 applicability under NIAC, thereby pointing to the flexibility in Common Article 3's application for protecting combatants in armed conflict. ${ }^{90}$ Common Article 3 in the context of the US war on terror would,

84. See Pejic, supra note 57, at 192.

85. Pejic, supra note 57, at 206.

86. See Pejic, supra note 57, at 191 (arguing that, "Common Article 3 expressly refers to 'each Party to the conflict', [sic] thereby implying that a precondition for its application is the existence of at least two 'parties').

While it is usually not difficult to establish whether a state party exists, determining whether a non-state armed group may be said to constitute a 'party' for the purposes of Common Article 3 can be complicated, mainly because of lack of clarity as to the precise facts and, on occasion, because of the political unwillingness of governments to acknowledge that they are involved in a non-international armed conflict. Pejic, supra note 57 , at 191.

87. See MELzer, supra note 75, at 256-57 (contending that, on the basis of the intensity of hostilities and the organizational structure of the insurgency, an isolated incident can be brought under the purview of HRL within the context of NIAC).

88. MELZER, supra note 75, at 256-57.

89. See generally, Hamdan's Illumination of Article III, supra note 49.

90. Hamdan v. Rumsfeld, 548 US 557, 635 (2006). The Hamdan Court's reliance on Geneva Convention's Common Article 3 is not only significant at several levels, but also exudes brilliant jurisprudence by Justice Stevens, as I have noted elsewhere. See Hamdan's Illumination of Article III, supra note 49. My view is that Hamdan as case law would imply that Common Article 3 of Geneva Conventions applies to members of al-Qaeda in the US government's ongoing war on terror. Moreover, by recognizing the binding impact of the relevant provisions of Article 3 in Hamdan, cases can be made against all signatory states to keep them from passing sentences or carrying out executions against members of Al-Qaeda without any previous judgment pronounced by a regularly constituted court. This is corroborated in Justice Stevens' observation: "Common Article 3, then, is applicable here and ... requires that Hamdan be tried by a 'regularly constituted court affording all the judicial guarantees which are recognized as indispensable by civilized peoples." Id. at 63132 (alteration added). While the term "regularly constituted court" is not specifically defined in either Common Article 3 or its accompanying commentary, other sources disclose its core meaning. The commentary accompanying a provision of the Fourth Geneva Convention, for example, defines "regularly constituted" tribunals to include "ordinary military courts" and "definitely exclude[] all special tribunals." $I d$. at 729 (alteration added). Similarly, commenting on military tribunals' requirement of uniformity Laws of War, Justice Kennedy 
thus, apply unequivocally to members of Al-Qaeda or Al-Qaeda in the Arabian Peninsula, as it did to Salim Hamdan. Failure to characterize the current global war on terror as a NIAC leads to a denial of an applicable protection paradigm of the Geneva Conventions, which is not legally sustainable. It is important to note that the various targets of these NIACs must, therefore, be rescued from the unregulated space of IHL, for which, the inquiry must now develop a nuanced understanding as to who could be a member for the purpose of its application.

\section{B. Who is a Member for Applicability of International Humanitarian Law?}

Analysis of the legitimacy of targeted killing requires a comprehensive evaluation of the target who may be a functional combatant in the war conflict paradigm equation. In this paradigm, a target cannot be decoupled from the theater of hostilities, as the characteristics of the physical location grants the target certain rights based on the nature of hostilities, a framework that can be recognized as regionalizing a functional combatant. The analysis thus far can infer that the current hostilities between the United States and Al-Qaeda or Al-Qaeda in the Arabian Peninsula, for the most part, would fall under NIAC. The next level of inquiry is to identify whether international law-more specifically, IHLprovides guidance to an evaluation of who can be targeted. Setting aside the rather complex interaction between two competing rights - the right to life of the targeted individual versus the right to targeted killing - the analysis now must examine the membership of the functional combatant.

Driven primarily to support indefinite detention, the legal landscape post-9/11 has developed a new class of combatants, called "enemy combatant[s]," whose legal status has been the subject of numerous commentaries and court opinions. ${ }^{91}$ Arguably as the enemy combatant classification presented structural hurdles for targeted killing, a newer class of combatants was coined under the rubric of functional combatant. As the frequency of NIACs continues to rise on the global stage, lines between civilians and combatants are increasingly being blurred. To argue that the functional combatant designation would allow flexibility in categorizing

noted:

Common Article 3's standard of a 'regularly constituted court affording all the judicial guarantees which are recognized as indispensable by civilized peoples,' . . . supports, at the least, a uniformity principle similar to that codified in $\S 836(\mathrm{~b})$. The concept of a 'regularly constituted court' providing 'indispensable' judicial guarantees requires consideration of the system of justice under which the commission is established, though no doubt certain minimum standards are applicable.

Id. at 643 (internal citations omitted) (alteration added). See ICRC OPINION PAPER, supra note 45, at 3; On the Judicial Treatment of Guantánamo Detainees, supra note 50, at 1006, n. 48.

91. See On the Judicial Treatment of Guantánamo Detainees, supra note 50, at 88-90. 
individuals who may or may not be actively engaged in combat, and yet, can be a legitimate target for killing by the state, would be conceptually flawed for various reasons.

What can be viewed as flexibility by the targeting state in conveniently identifying a wide range of individuals is, indeed, difficult to reconcile with the international law framework. This difficulty stems from the indeterminacy of categorization that comes from an absence of adequate disaggregation of functionalities. The existence of two overlapping theories to categorize the nature of a combatant-either defining them under continuous fighting function ("CFF"), ${ }^{92}$ or under continuous combat function ("CCF") ${ }^{93}$ - creates a functional indeterminacy in designating a functional combatant. This creates operational difficulty for IHL application for designating a target within the context of NIAC.

Linguistically, "fighting" may have a more restrictive connotation than "combat." Therefore, the restriction placed on the CFF model can be relaxed by converting to the CCF model. This would allow the imposition of the functional combatant status on individuals who may function in support roles without actually engaging in direct combat. Perhaps by including roles as varied as participants in political and religious leadership activities, financial contributors, informants against occupying or invading forces, collaborators and insurgent sympathizers, or, even vehicle drivers and other service providers, CCF designation can encapsulate a larger number of individuals. This expanded interpretation of operational

92. Post-9/11 escalation of asymmetric warfare has given rise to various models to adequately define insurgents or terrorists involved in armed hostilities with states. Difficulties in legally encapsulating "enemy combatants," prompted the legal community to tinker with various definitional paradigms applicable to combatants, based on duration, scope and intensity of hostilities. The continuous fighting function (CFF) vs. continuous combat function (CCF) distinction is one such example, on which no consensus has emerged as of yet. Melzer takes the position that CFF would better capture the essence of combatant in evolving hostilities paradigm of today. See MELzER, supra note 75, at 321. Chesney argues that, "[t]he CFF test is the 'CCF' (CCF) standard to which the ICRC refers in the Interpretive Guidance." Chesney, supra note 51, at 44, n. 174 (alteration added). Commenting on CCF, Chesney notes:

On this model, not all persons associated with the non-state party would count as combatants for purposes of distinction. Rather, only those members who directly participate in hostilities on a regular base would so qualify; other group members would remain civilian. From a policy perspective, the desirability of this approach of course depends entirely on how one interprets the concept of 'direct participation' and the requirement of continuity.

Chesney, supra note 51, at 44. I concur with Chesney that both models could invite controversy and might exclude some members to the inclusion of some others who decidedly may not belong. Chesney has rightly noted that "[t]he law on point, unfortunately, is simply not determinate enough to resolve that dispute." Chesney, supra note 51, at 44 (alteration added).

93. Chesney, supra note 51, at 44. 
functionalities ${ }^{94}$ could, therefore, subject a larger group of individuals to the hostilities paradigm. Therefore, CCF can bring a much larger group of individuals under the broader umbrella of functional combatant, regardless of whether or not such characterization immunizes a state from charges of extrajudicial killing. ${ }^{95}$

Whether we follow CCF's broader meaning of combatant or CFF's restricted meaning, none of these frameworks can fully address a state's heightened obligation towards minimizing civilian casualties. ${ }^{96}$ The framework of targeted killing is conceptually complex. Thus, to adequately determine the status of an individual within the conflict paradigm, we are required to delineate between the legal legitimacies of two interacting paradigms: the functional combatant paradigm and the civilian protection paradigm. For example, if a state deliberately targets a functional combatant and knowingly becomes complicit in protecting civilians in order to eliminate such combatant via targeting, the act may be deemed illegal. Thus, any analysis of the legitimacy of targeted killing would turn on fully evaluating the context and scope of such acts. In such evaluation, the predominant focus must be on establishing whether imputing an expanded meaning of functional combatant would necessarily translate into a gross denial of civilian rights to live in the proximate vicinity of hostilities. Evaluating through this prism, it can be argued that, widespread civilian deaths arising out of continued drone strikes in Pakistan, ${ }^{97}$ Afghanistan, ${ }^{98}$ and in the Arabian Peninsula, ${ }^{99}$ can be characterized as state complicity. Despite the targeting state's focused pursuit on suspected terrorists, targeted killing can never rise to a level of legal legitimacy in such circumstances.

The above discussion prompts us to question why there is a severe lack of accountability mechanisms for civilian protection. Could this be attributed to the United States' failure in adopting a legally permissible means to kill by expanding the definition of a combatant? Or, is it because the state conducting the targeted killing strikes is not providing transparency related to the killings? Focusing on either one of these issues would propel us to seek the much needed parameters to define functional combatant targeted for such strikes. Yet, constructing such definitional parameters might be difficult to achieve in practice. This is because if there is a right to kill functional combatants, this right cannot be exercised

94. Chesney, supra note 51, at 44.

95. Here I draw attention to the dangers of an expanded reading of a wrong model, whereby civilians or individuals not explicitly belonging to terrorists groups can be wrongfully targeted.

96. See supra notes 91, 93-94 and accompanying text.

97. See Bergen \& Tiedemann, supra note 46 (discussing air strikes by US drones in Pakistan and Afghanistan).

98. Bergen \& Tiedemann, supra note 46.

99. Bergen \& Tiedemann, supra note 46. 
without an appropriate status determination of the target. Such determination becomes difficult and imprecise under the existing IHL guidelines, ${ }^{100}$ and the $\mathrm{CFF} / \mathrm{CCF}$ dichotomy, ${ }^{101}$ for the following suggested reasons.

First, if an individual is determined to be a functional combatant under the $\mathrm{CFF} / \mathrm{CCF}$ model, no temporal delimiting criteria exists in practice to prevent him from remaining a target in perpetuity. This raises a significant question that is somewhat akin to the temporal expansion of indefinite detention: when does a target cease to become a target?

Second, the scope, content, and membership of hostilities depend to a large extent on ground intelligence, which suffers from imprecision, ${ }^{102}$ coercion, ${ }^{103}$ and unreliability. ${ }^{104}$ Imprecise intelligence ${ }^{105}$ based drone strikes from remote locations inevitably invites a higher probability of civilian deaths. The CCF model neither provides assurance of robustness of the evidence collection mechanism, nor exhibits confidence in the deliberation mechanism that uses such evidence to execute a targeted killing. Therefore, in expanding the functional combatant framework from $\mathrm{CFF}$ to $\mathrm{CCF}$, a state can enhance the potential for larger civilian casualties during conflicts. Unfortunately, such designation framework does not have an adequate preventive mechanism to prevent, minimize, or eliminate excessive civilian casualties.

For the proponents of state-sponsored targeted killing, CCF is a very attractive model, as it allows the flexibility to incorporate targeted killing under Common Article 3's invocation of NIAC. ${ }^{106}$ Despite this flexibility, this is a fundamentally flawed model. While a CCF can theoretically exist, it is practically impossible to implement such paradigm under international law, ${ }^{107}$ because its proponents may argue for a combat to have neither

100. See Chesney, supra note 51.

101. See Chesney, supra note 51, at 44 (discussing the differences between the CFF and CCF categorizations of combatants).

102. See Bergen \& Tiedemann, supra note 46 (noting that in 82 drone attacks, $750-1000$ civilians died between 2006 and 2009, while only 20 intended targets were killed).

103. I have discussed this issue at length elsewhere; see On the Judicial Treatment of Guantánamo Detainees, supra note 50 (noting how often times evidence collected for terrorist prosecution or targeting terrorist have been unreliable on account of having been obtained via coerced confession).

104. See supra note 13 (stating that 700 persons have died in attacks killing 14 intended targets).

105. See supra note 13 (discussing two clear issues regarding operating drones from remote locations: (1) targeting; and (2) command and control).

106. See Pejic, supra note 57.

107. Some scholars reject CFF on the grounds of excluding individuals who primarily act as a support function in the broader organization of insurgencies. See MELzER, supra note 75 , at 320-21. Therefore, not including political and religious leaders, financial backers, informants and collaborators would imply that they may not be part of CFF, and thus cannot be targeted, which goes against the proponents of the broader right to kill. See Kenneth 
temporal nor geographical limitation, yet, its invocation would certainly invite untenable logical consequences. ${ }^{108}$ Such flawed conflict models described here can neither continue in a legal vacuum, nor could they evolve in an unregulated IHL paradigm. ${ }^{109}$ They can only be supervised under Common Article 3 within a NIAC context. Since Common Article 3 has neither envisioned combat scenarios that are unending, perpetual, ${ }^{110}$ and co-existing across multiple non-contiguous regions, ${ }^{111}$ nor endorsed an allpervasive combatant designation, ${ }^{112}$ targeted killing based on a CCF model

Watkin, Opportunity Lost: Organized Armed Groups and the ICRC "Direct Participation in Hostilities” Interpretive Guidance, 42 N.Y.U. J. INT'L L. \& POL. 641, 645-46 (2010). If we are to embrace the paradigm that does not include these service providers, we would default to embracing either the CCF or some variant of a CCF model. As I have noted in this Article, adopting CCF would expand the pool of individuals allowing States to target more civilians under a fuzzy framework of combatant model that does not adequately distinguish between civilians and combatants.

108. See supra note 107 and accompanying text.

109. Here I draw attention to State practice where States prefer to operate under IHL paradigm, while the elements of hostilities might point to international humanitarian rights law applicability. This lack of synchrony between theoretical developments in law and practical elements on the ground creates an uncertainty surrounding permissive conduct of hostilities within the context of HRL. In this scenario, a State might invoke IHL guidelines, yet might be able to exhibit behaviors that fall outside IHL norms, effectively relegating the conduct of hostilities to conduct in an unregulated space. See supra text accompanying note 31 (discussing the scope of HRL and international IHL). The US' official position is noteworthy, both in the context of its invocation of specific legal dimension and its assertion of a specific policy position. While articulating the government position on targeted killing, the legal adviser to the Department of State recently provided the administration's legal justifications for targeted killings, noting that "the use of lawful weapons systemsconsistent with the applicable laws of war-for precision targeting of specific high-level belligerent leaders when acting in self-defense or during an armed conflict is not unlawful, and hence does not constitute 'assassination." STEPHEN L. CARTER, THE Violence OF Peace: America's War In the Age of Obama (2011). This adoption of targeted killing, according to Harold Koh, was based on right to self-defense under HRL, as "the United States is "in an armed conflict with Al Qaeda, as well as the Taliban and associated forces ...."' Harold Koh, Legal Adviser, Dep't of State, Keynote Address at the Annual Meeting of the American Society of International Law (Mar. 25, 2010) (alteration added). Clearly, while this is a policy statement, it does not address details, such as scope, transparency, and criteria. The questions of who can be targeted, how we can be assured that civilians are not being killed indiscriminately and if personnel involved are properly trained continue to rise above the broad stroke justifications. We are compelled to ask a multitude of questions as to where the substantive procedural safeguards against escalating evidences of civilian deaths are and what steps are being taken to close the accountability gap.

110. See W. Hays Parks, Part IX of the ICRC "Direct Participation in Hostilities" Study: No Mandate, No Expertise and Legally Incorrect, 42 N.Y.U. J. INT'L L. \& POL. 769 (2010) (explaining why continuity requirement of HRL may be relaxed for State actors).

111. See sources cited supra note 75 (discussion on Common Article 3, providing guidelines for its trigger) and Tadic Judgment, supra note 57 (examining the judgment's main holdings while articulating how this judgment may have open the door for various other extrapolations in asymmetric warfare).

112. See sources cited supra note 92. 
may not find legitimacy in IHL. Moreover, as I shall identify below, IHL's necessity-proportionality-distinction triad would further reject targeted killing based on a CCF model of functional combatant.

\section{Proportionality vs. Right to Self-Defense}

Within the broader context of armed conflict, the idea of self-defense has not only invoked strong emotive sentiments, it has also generated significant jurisprudence on state rights. ${ }^{113}$ International law prescribes a set of specific guidelines in which a state under attack can exercise its right to self-defense. ${ }^{14}$ Such doctrine of self-defense emanates from a multidimensional manifold of international law that straddles various individual paradigms, such as the UN Charter, IHL, and HRL. ${ }^{115}$ Given that international law manifests itself through these dimensions, any right to targeted killing must spring forth from these dimensions only. Logically, we ponder whether such a right to targeted killing can also spring from NIAC or, must it be acquired as a derivative right under the self-defense right in article 51 of the UN Charter. ${ }^{116}$ The International Court of Justice

113. Compare Thomas M. Franck, Who Killed Article 2(4)? or Changing Norms Governing the Use of Force by States, 64 AM. J. INT'L L. 809, 809-10 (1970), with Louis Henkin, The Reports of the Death of Article 2(4) Are Greatly Exaggerated, 65 AM. J. INT'L L. 544, 544-45 (1971). Jurisprudential developments provide guidance regarding timing and context of self-defense rights trigger mechanism. See also Military and Paramilitary Activities in and Against Nicaragua (Nicar. v. US), 1986 I.C.J. 14, at paras. 194, 246 (June 27) [hereinafter Military and Paramilitary Activities]; Oscar Schachter, The Right of States to Use Armed Force, 82 Mich. L. REv. 1620, 1633-34 (1984) (noting that in the context of self-defense, force is proportionate only if it used defensively and if it is confined to the objective). Pakistan and Yemen may have even consented to targeted drone killings by the United States in their territory. Eric Schmitt \& Mark Mazzetti, In a First, US Provides Pakistan with Drone Data, N.Y. TIMES, May 13, 2009, http://www.nytimes.com/2009/05/14/ world/asia/14drone.html, archived at http://perma.cc/QN6E-JEQZ; Mary Ellen O'Connell, Drones Under International Law, in WASHINGTON UNIVERSITY LAW: WHITNEY R. HARRIS World LaW Institute International Debate Series 5 (2010), archived at http://perma.cc/H2LM-W9V4 (making observations on when the right to self-defense gets triggered under terrorist threat); Joby Warrick \& Peter Finn, CIA Director Says Secret Attacks in Pakistan Have Hobbled al-Qaeda, WAsh. Post, Mar. 18, 2010, http://www. washingtonpost.com/wp-dyn/content/article/2010/03/17/AR2010031702558.html, archived at http://perma.cc/FUP3-8WHH.

114. Article 2(4) of the United Nations Charter prohibits member States from using force against the territorial integrity or political independence of any state, or in any other manner inconsistent with the purposes of the United Nations. U.N. Charter arts. 1(1), 2(4). In this context, the right to self-defense is triggered under (i) Article 2(4)'s exceptions, (ii) Article 51 's preservation of the right of self-defense, and (iii) Chapter VII mechanism whereby the Security Council may authorize the use of force. See U.N. Charter arts. 39, 42, 51.

115. See M.A. Weightman, Self-Defense in International Law, 37 VA. L. REV. 1095-1115 (1951).

116. U.N. Charter art. 51. 
("ICJ") mandates an inordinately high threshold ${ }^{117}$ for States triggering the article 51 self-defense right that may not necessarily permit remotely operated targeted killings on most occasions, especially when a state violates the sovereignty of another state to attack non-state actors. The United Nations' Security Council resolutions, $1368^{118}$ and $1372^{119}$ do not explicitly impute armed attack by non-state actors on the state whose physical territory was used. Therefore, the issue of violations of territorial sovereignty of a state presents complex dynamics. This complexity does not go away even if the targeted killing is not designed to violate the sovereignty of the state, or if it is being executed with state consent.

Against the above backdrop, a "robust self-defense model" to justify targeted killing ${ }^{120}$ has been advanced in recent scholarship. ${ }^{121}$ This is inconsistent within the NIAC context of IHL, as it is predominantly a misapplied invocation of the lex specialis rule of international law. ${ }^{122}$ The robust self-defense model attempts to validate extrajudicial killings by providing interpretative gloss of legal justifiability by contradicting various delimiting principles of IHL and HRL. ${ }^{123}$ Some of these contradictions come in part by impermissibly conflating jus ad bellum and jus in bello, ${ }^{124}$ and, in part by misapplying the ICJ's nuclear weapons advisory opinion. ${ }^{125}$ Although misapplied, this attempted doctrinal foray could mistakenly attribute new derivative rights on states from scenarios that do not reconcile with their applicable legal principles. ${ }^{126}$ The invocation of an extreme

117. See Military and Paramilitary Activities, supra note 113.

118. S.C. Res. 1368, U.N. Doc. S/RES/1368 (Sept. 12, 2001).

119. S.C. Res. 1372, U.N. Doc. S/RES/1372 (Sept. 28, 2001).

120. See Targeted Killing as Active Self-Defense, supra note 19.

121. See Targeted Killing: Self-Defense, Preemption, and the War on Terrorism, supra note 21 .

122. For textual support of lex specialis in this context, see Hague Convention (V) Respecting the Rights and Duties of Neutral Powers and Persons in Case of War on Land (1907), art. 5. Commentators have noted that IHL and HRL apply coextensively and simultaneously unless there is a conflict between them. See U.N Doc. E/CN.4/2005/7, supra note 29, paras. 46-53; U.N. Doc. A/HRC/4/20, supra note 29, paras. 18-19; U.N. Doc. A/HRC/11/2/Add.5, supra note 29, paras. 71-73, 83; U.N. Doc. A/HRC/4/20/Add.1, supra note 29, at 342-61; U.N Doc. E/CN.4/2006/53/Add.1, supra note 29, at 264-65. For additional discussion of its applicability, see Parks, supra note 110, at 799.

123. See Targeted Killing as Active Self-Defense, supra note 19.

124. See Robert Sloane, The Cost of Conflation: Preserving the Dualism of Jus ad Bellum and Jus in Bello in the Contemporary Law of War, 34 YALE J. INT'L L. 47, 52 (2009).

125. Legality of the Threat or Use of Nuclear Weapons, Advisory Opinion, 1996 I.C.J. 226, para. 25 (July) [hereinafter Nuclear Weapons Advisory Opinion]; Legal Consequences of the Construction of a Wall in the Occupied Palestinian Territory, Advisory Opinion, 2004 I.C.J. 136, para. 106 (July 9) [hereinafter Construction of a Wall]; Armed Activities on the Territory of the Congo (Democratic Republic of the Congo v. Uganda), 2005 I.C.J. 168, para. 216 (Dec. 19) [hereinafter Congo v. Uganda].

126. See Collateral Damage, supra note 36, at 680 n.7. 
circumstance for justifying an application in a different circumstance with a much lower threshold is an unfortunate trend in international law that has emerged after 9/11. The motivation behind such an anomalous legal argument is not the objective of my inquiry. Yet, states have been engaged in invoking such a flawed self-defense argument to immunize themselves from war crimes charges. ${ }^{127}$ It is, therefore, imperative, to recognize this emerging trend of a misguided invocation of article 51, especially within the broader context of protecting human rights of civilians in post-9/11 hostilities framework.

Relaxing the preconditions for triggering article 51's right to selfdefense would allow for a nuanced discussion by focusing on specific constraints to determine how the right to targeted killing might flow. In this context, all three different strands of international law-article 51's customary right, ${ }^{128}$ IHL's just ad bellum, ${ }^{129}$ and HRL's jus in bello ${ }^{130}$ make one thing clear: the right to self-defense comes with the compliance requirements of necessity, proportionality, and distinction.

\section{Necessity in International Humanitarian Law}

The requirements of necessity are more clearly articulated within the context of customary self-defense. Consensus emerging from existing jurisprudence would indicate that the requirement of necessity turns on two specific steps: (1) the least harmful means test ${ }^{131}$ and (2) the imminence test. ${ }^{132}$ Predicated on granulating necessity as composed of three parts-

127. See Collateral Damage, supra note 36 (discussing the divergence between state's invocation of self defense right and targeted civilians' right to life).

128. See U.N. Charter art. 51.

129. See generally Christine Gray, International LaW AND the Use of ForCe 133 (2004) (noting that the war on terror may have brought significant changes in the law of selfdefense, while questioning the legitimacy of military powers' triggering regime changes for vested interest); Robert Kolb, Origin of the Twin Terms Jus ad Bellum/Jus in Bello, 320 INT'L REV. RED CROSS 554 (1997) (seeking clarity to the sources of laws of war in literature and practice); Judith Gail Gardam, Proportionality and Force in International Law, 87 AM. J. INT'L L. 391, 411 (1993) (dissecting the interaction between proportionality and force within the context of laws of war).

130. See Gardam, supra note 129, at 411.

131. Jurisprudence on application of "least harmful means" test in satisfying the military necessity component has matured in the context of asymmetric war. See HCJ 769/02 The Public Committee Against Torture in Israel v. Israel 2006(2) PD 459, ๆ 16 [2006] (Isr.); see also Construction of a Wall, supra note 125 (Separate Opinion of Judge Higgins). Melzer finds the test's support in international law as well. See also MELzER, supra note 75, at 95112.

132. For legal analysis of "imminence," see generally Chesney, supra note 51; see also Targeted Killing of Suspected Terrorists, supra note 27 (examining the legality of targeted killing of suspected terrorists under both IHL and HRL). In this Article, I question the 
qualitative, quantitative, and temporal necessity - a newer necessity analysis has also been proposed. ${ }^{133}$ The elegance of this analysis comes from its granularity. It allows for the stand-alone deconstruction of its constituent elements, while allowing both the least harmful means and the imminence requirements to be tested separately across each, as noted in comments elsewhere. ${ }^{134}$ I will analyze both of these methodologies separately.

Under the least harmful means test, the engaging state must determine whether there exists a comparable and compatible alternative to killing with a concomitant lesser threshold of violence as a means of self-defense. ${ }^{135}$ Applying this test to the US involvement in any one of the current theaters of hostilities would invite us to assess a set of indicative factors. Evaluating the various factors - administrative stability of the region, ${ }^{136}$ uncertainty over the military-terrorist nexus, ${ }^{137}$ and confusion over willingness versus capability of the countries involved ${ }^{138}$ might render the applicability of a least harmful means test difficult or, non-deterministic. Yet, this nonavailability may not provide iron clad reasoning for the necessity principle to trigger a state's right to targeted killing. Even if the least harmful means test yields no deterministic outcome, the entire deliberative process must be defaulted under the second criterion of imminence test, ${ }^{139}$ which turns the inquiry into two distinct requirements that can be met by answering in the affirmative to the following questions: (1) is the threat imminent; ${ }^{140}$ and (2)

application and context of "imminence" as has been discussed in the aforementioned two works.

133. See MELzer, supra note 75, at 100-102.

134. See infra Part IV.D.

135. The crux of the issue is whether "military necessity" can be fulfilled without resorting to lethal force or without loss of life, an inquiry that turns into adequately capturing the full scope and context of military necessity. Although Israeli domestic court opinions are cited as framework for how this test should be applied in practice, some scholars find both the absence of under developed theory behind necessity paradigm in international law and reliance on domestic cases somewhat problematic. See MELzER, supra note 75, at 101. For other studies on this test, see generally R.S. Schondorf, The Targeted Killings Judgment: A Preliminary Assessment, 5 J. INT'L CRIM. JUST. 301 (2007) (examining the judgment of Israeli Court in cases of targeted killing in offering a nuanced view of the judgment's relationship to the development of the laws of armed conflict).

136. See Mosharraf Zaidi, The Lies They Tell Us: Can the Pakistani Government's Web of Deceit Survive the Death of Osama Bin Laden?, Foreign Policy, May 2, 2011, http://www.foreignpolicy.com/articles/2011/05/02/the_lies_they_tell_us, archived at http://perma.cc/9SVT-6NKR.

137. See Peerzada Ashiq, 'Pakistan Army, Terror Groups Nexus Exposed" HindustaN TIMES, Oct. 2, 2011, http://www.hindustantimes.com/india-news/pakistan-army-terrorgroups-nexus-exposed/article1-752724.aspx, archived at http://perma.cc/S6AV-W2PV.

138. See id.

139. See sources cited supra notes 131, 132 and accompanying text.

140. The inquiry of whether the threat is imminent finds its force in The United Nations Basic Principles for the Use of Force and Firearms by Law Enforcement Officials which are widely adopted by police throughout the world. Article 9 provides that: 
will the elimination of threats eliminate potential future attacks? ${ }^{141}$

Pronging out the second distinct requirement, proponents of targeted killing would argue, that any elimination of a threat would result in the removal of future related threats. ${ }^{142}$ The legitimacy of this line of argumentation turns on determining what is meant by "related" in this context. However, related could sometimes be a nebulous concept, ${ }^{143}$ especially, when it is stripped of its underlying parameters and is used as a 'means to an end' in justifying actions related to a targeted killing. Given the relative weakness in structuring arguments on the meaning of "related," I shall not belabor a detailed inquiry. Rather, let us relax the condition and assume that, the criterion in question is satisfied with respect to a determination of whether the threat could be eliminated via killing, such

Law enforcement officials shall not use firearms against persons except in self-defence or defence [sic] of others against the imminent threat of death or serious injury, to prevent the perpetration of a particularly serious crime involving grave threat to life, to arrest a person presenting such a danger and resisting their authority, or to prevent his or her escape, and only when less extreme means are insufficient to achieve these objectives. In any event, intentional lethal use of firearms may only be made when strictly unavoidable in order to protect life.

U.N. Congress on the Prevention of Crime and the Treatment of Offenders, Basic Principles for the Use of Force and Firearms by Law Enforcement Officials, Havana, Cuba, Art. 9 (Aug. 27-Sept. 7 1990) [hereinafter UN Basic Principles]. Scholars caution about the restricted framework needed for the use of lethal force. See YorAm DinsteIn, WAR, AGGRESSION AND SELF-DEFENCE 167 (2001) (describing the restrictive approach). Author Alston noted in this context, "The third key area of controversy is the extent to which States seek to invoke the right to self-defense not just in response to an armed attack, but in anticipatory self-defense, or alternatively, as a pre-emptive measure in response to a threat that is persistent and may take place in the future, but is not likely to take place imminently." See Alston, supra note 28, para. 4. Some scholars expand this restricted approach somewhat by incorporating into permissibility some necessity that is characterized by instant need for action. See also Thomas M. Franck, What Happens Now? The United Nations After Iraq, 97 Am. J. Int'L L. 607, 619 (2003); Thomas M. Franck, Recourse to Force: State Action Against Threats And ARMed AtTACKs (2002); R.Y. Jennings, The Caroline and McLeod Cases, 32 Am. J. InT'L L. 82, 92 (1938); Christian J. Tams, The Use of Force Against Terrorists, 20 EUR. J. INT'L LAW 359, 378-83 (2009). However, no one advocates the scorched earth policy the US government has advocated in codifying into practice policy premised on lethal force at the slightest evidence of threat.

141. This refers to a subjective evaluation that must accompany pre-attack deliberation to carefully identify if the elimination of the instant threat will necessarily prevent future attacks.

142. See Guiora, supra note 19.

143. This Article challenges the various rationales put forth by the proponents of targeted killing via drone strikes. In this context, I draw attention to the fact that, oftentimes when a particular individual or a group of individuals are killed via remotely operated drone strikes, the administration immediately justifies the killing as part of a self-defense mechanism and attempts to link such targeted assassinations as a preventive mechanism against killing of American citizens or destruction of American interests. As has been highlighted in this work, not much concrete proof has ever been put forward in terms of linking most of these targeted killings with future prevention of terrorism. 
that no future attack would take place. Now, the analysis would logically turn to evaluating the context and complexity of imminence for the necessity analysis.

Assessing an imminent threat is becoming increasingly difficult in today's asymmetric warfare. Or rather, assessing the legal justification of recent targeted killings, at times solely based on the criteria of imminence, ${ }^{144}$ has become an Achilles heel of international jurisprudence. ${ }^{145}$ First, by its very nature alone, obtaining credible evidence to determine whether an attack is imminent is difficult. The difficulty might be even more pronounced when asked to determine whether or not the magnitude of such attack would be sufficiently intense. Yet, nations like the United States ${ }^{146}$ and Israel ${ }^{147}$ have engaged in targeted killing by simply applying one of these two criteria. Second, most times the lack of transparency surrounding the perceived threat makes it difficult to assess a true imminence from a manufactured imminence-more importantly, when such threat is to be used specifically to justify a targeted killing. National security invocation allows classified material to remain closed to third party review, making independent verification of a state claim of imminent threat a difficult proposition. This lack of transparency makes it virtually impossible to judge a state's compliance against the imminence requirement. However, the recent surge in targeted killings by the United States makes it imperative to engage in a stricter review of such acts against prescribed IHL guidelines. Moreover, escalating frequency of targeted killings and the remoteness of regions where they occur ${ }^{148}$ make it difficult to corroborate the state rationale of imminent threat. Consequently, applying the imminence doctrine has become legally indeterminate.

The necessity argument for targeted killing under article 51 within the context of "imminent threat" resides on even weaker fundamentals. The frequency of recent killings, lack of transparency surrounding necessary deliberations, and publicly available evidence surrounding the lack of

\footnotetext{
144. See sources cited supra notes 131, 132 and accompanying text.

145. Here I draw attention to the uncertainty surrounding what constitutes "imminent."

146. See Alston supra note 28.

147. See Asa Kasher, Operation Cast Lead and the Ethics of Just War, Azure (2009), http://www.azure.org.il/include/print.php?id=502, archived at http://perma.cc/Q6MV-LH68; See also The Operation in GaZA - Factual And Legal Aspects, Israel Ministry of AFFAIRS 14-26 (2009), archived at http://perma.cc/7A73-8PWN; Report of the Independent Fact-Finding Committee on Gaza: No Safe Place, Jews For Justice For Palestinians (2009), http://jfjfp.com/?p=2649, archived at http://perma.cc/K7S8-8X3R [hereinafter Report of the Independent Fact-Finding Committee]. For the Organization of the Islamic Conference's response, see Islamic Conference, Final Communique Of The Expanded Extraordinary Meeting Of The Executive Committee At The Level Of Foreign Ministers ON THE Ongoing ISRAELi Assault ON GAZA (2009), archived at http://perma.cc/Z9V9-UQML.

148. Report of the Independent Fact-Finding Committee, supra note 147, 97.
} 
imminent threat bolster this viewpoint. Moreover, the imminence test centers on making value judgments on whether the elimination of the target would necessarily result in such threats being eviscerated. ${ }^{149}$ Again, given the invocation of classified material used in scoping and defining such targets, it is very difficult to judge prima facie the sanctity of such assertions. Especially instructive in this context, is the disturbing trend of elevating the status designation of a target after the consummation of the killing. Often times, a virtually unknown individual has been elevated and classified as belonging to a higher echelon of either Al-Qaeda or Al-Qaeda in the Arabian Peninsula. ${ }^{150}$ For example, in a recent example of targeted assassination involving Anwar al-Awlaki, evidence suggests, that his organizational status has been elevated post-assassination. ${ }^{151}$ Besides bolstering the imminence requirement, this ex post facto elevation introduces implementation difficulties. Interestingly however, these examples of the post-mortem status elevation provide indication that there are other preconditions that must be reviewed-including a combatant's ability to inflict intense violence and a confirmation that elimination of such combatant would necessarily prevent future threats. Both would be difficult to achieve in practice within the context of such extrajudicial killings.

\section{E. Proportionality in the Context of Targeted Killing in International Humanitarian Law}

The right of self-defense is a legitimate right of the state that flows naturally out of the multi-dimensional space of international law. While each strand of this multi-pronged legal space can support the right to selfdefense, its derivative right of targeted killing must be restricted within appropriate constraints. Despite IHL's ever-changing doctrinal development, few of its tenets remain ontologically fixed. ${ }^{152}$ A right to life springs forth more naturally than a derivative right such as the right to targeted killing. This conceptual dichotomy might explain why there may exist a natural conflict between the two rights. In this context, IHL promises to guide humanity to legally identify at a fundamental level what is a

149. See sources cited supra note 132 and accompanying text.

150. See Dina Temple-Raston, Eliminating Al-Qaida's No. 3, Again and Again, NPR, June 2, 2010, http://www.npr.org/templates/story/story.php?storyId=127352134, archived at http://perma.cc/PNR6-HVH3.

151. See Greg Miller \& Alice Fordham, Anwar al-Aulaqi Gets New Designation in Death, The Washington Post NAtional (Sept. 30, 2011), http://www.washingtonpost.com/blogs/ checkpoint-washington/post/aulaqi-gets-new-designation-in-death/2011/09/30/gIQAsbF69K_ blog.html, archived at http://perma.cc/PR9U-3UFR.

152. See Narrative of Dehumanization, supra note 8, at 161-63 (discussing ontological dimensions in understanding various instances of interactions between source of right and framework to exert such right). 
"right" 153 and whether the civilians" "rights"154 prevail over those of the combatants. This must remain true even when politicized global events bring in a natural tendency to shape the law's contour via the distorting effect of military power. Thus, Justice Aharon Barak has rightfully cautioned us against the deleterious effect of military power, as he noted, "[e]ven when the cannons speak and the Muses are silent, law exists and operates, determining what is permitted and what forbidden, what is lawful and what unlawful." 155 With such spirit of law in mind, we must critically examine whether the right to targeted killing by remote drone strikes can be contextualized within the proportionality principles of IHL.

In the current context, the principle of proportionality ${ }^{156}$ requires that

153. Narrative of Dehumanization, supra note 8, at 708 .

154. Narrative of Dehumanization, supra note 8, at 709.

155. HCJ 7015/02 Ajuri v. IDF Commander 56(6) PD 352, ๆ 41 [2002] (Isr.) (citing HCJ 2161/96 Sharif v. Home Guard Commander IsrSC [35], at 491 (citing the remarks of thenVice-President Justice Landau in HCJ 390/79 Dawikat v. Government of Israel [36], at 4)).

156. In my view, the principle of proportionality provides the strongest civilian protection available in customary international law. In defining "civilian" and "civilian populations" AP I States, "The presence within the civilian population of individuals who do not come within the definition of civilians does not deprive the population of its civilian character." AP I, supra note 45, art. 50(3). AP I further States that civilian populations are protected from indiscriminate attacks, including attacks "which may be expected to cause incidental loss of civilian life, injury to civilians, damage to civilian objects, or a combination thereof, which would be excessive in relation to the concrete and direct military advantage anticipated." AP I, supra note 45, art. 51(5)(b). The principle of proportionality makes it mandatory for the military planners, under article 57(2)(a)(ii) of AP I, to "take all feasible precautions in the choice of means and methods of attack with a view to avoiding, and in any event to minimizing, incidental loss of civilian life, injury to civilians and damage to civilian objects." AP I, supra note 45, art. 57(2)(a)(ii). The humanitarian spirit of HRL makes it incumbent for a military planner to engage in a two-step process before targeting a particular object. This includes, (1) ensuring the aggressive maneuver is a viable military objective, and then (2) determining with reasonable accuracy whether the resulting collateral damage is proportional to the intended military objective. The principle of proportionality does not invalidate a military objective, but it provides some restrictive covenants surrounding military objectives to reduce civilian casualties in military operations. This restrictive framework of proportionality has come under attack from the military establishments, especially those who are engaging in aggressive military exercises predominantly on civilians. See Michael Byers, The Laws of War, US-Style, LONDON REV. OF BoOKS, Feb. 20, 2003, http://www.lrb.co.uk/v25/n04/byer01_html, archived at http://perma.cc/WXE3-QFVM. Additionally, in 2001 Secretary Rumsfeld referenced United States bombs hitting a civilian warehouse in Afghanistan in 2001, stating, "We're not running out of targets, Afghanistan is." Ben Kiernan, "Collateral Damage" Means Real People, BANGKOK POST, Oct. 20, 2002, http:/www.yale.edu/gsp/publications/ collateral_damage.html, archived at http://perma.cc/F2V3-ZTCK. The focal point of contention is the definitional confusion surrounding the concept of "military objective," because unless the military community is able to agree on what a military objective is, the military cannot agree on proportionality. See Understanding Collateral Damage Workshop: Project On The Means Of Intervention Carr Center For Human Rights Policy, John F. Kennedy School Of Government Harvard University (2002), archived 
there must be a balance between an original terrorist attack and the responding force of self-defense that may take the form of targeted killing. Some scholars have advanced the proposition that IHL's proportionality does not necessarily imply that state response of lethal force must not exceed in intensity in accordance with the level of original attack. ${ }^{157}$ However, self-defense mechanisms under article 51 of the UN Charter are rooted in constructing a calibrated response against initial attack. ${ }^{158}$ This is corroborated by textual interpretation of the Geneva stream of laws premised in defining proportionality within the twin context of prohibition and precaution in the AP I. ${ }^{159}$

Let us assume that, the state's article 51 self-defense right has been triggered in any one of the hostilities framework the US is currently involved in. Let us also accept the factual assumption of imminent threat in a non-strict sense-where no immediate attack has been identified. Now, let us introduce into the test scenario a set of functional combatants - spotted within a family compound in Waziristan. ${ }^{160}$ What happens if one of the options considered would involve launching Hellfire missiles from a UAV operated from a command center in Nevada ${ }^{161}$ with a specific objective of eliminating some identified members of Al-Qaeda? Does this right of targeted killing spring from AP I's two-pronged framework? If no civilian assessment is done a priori and, no balancing test comparing target value

at http://perma.cc/W25J-2YSY (noting proportionality and objectivity may have some mutual exclusivity, from a military perspective, making the implementation rather difficult). This has been adequately addressed by Judge Higgins in her dissent to the Nuclear Weapons Advisory opinion. Judge Higgins contended that:

The principle of proportionality, even if finding no specific mention, is reflected in many provisions of the Additional Protocol I to the Geneva Conventions of 1949. Thus, even a legitimate target may not be attacked if the collateral civilian casualties would be disproportionate to the specific military gain from the attack.

Nuclear Weapons Advisory Opinion, supra note 125, dissenting opinion of Judge Higgins, archived at $\mathrm{http}: / /$ perma.cc/6RHR-7H86.

157. See Richard Murphy \& Afsheen John Radsan, Due Process and Targeted Killing of Terrorists, 31 CARdozo L. Rev. 405, 418 (2009); Sean D. Murphy, The International Legality of US Military Cross-Border Operations from Afghanistan into Pakistan, 85 INT'L L. Stud. Ser. US Naval War Col. 109, 127 (2009).

158. See U.N. Charter art. 51. Proportionality requires an assessment of whether an attack that is expected to cause incidental loss of civilian life or injury to civilians would be excessive in relation to the anticipated concrete and direct military advantage. See AP I, supra note 48, arts. 51(5)(b), 57; JEAN- MARIE HENCKAERTS \& LOUISE Doswald-Beck, Customary InTERnATIONAL Humanitarian LAW Rules, ICRC, Rule 14 (2005) [hereinafter ICRC Rules].

159. See U.N. Charter art. 51.

160. See Mayer, supra note 46 (providing a detailed description of various drone strikes); see also, Scott Shane, C.I.A. Is Disputed on Civilian Toll in Drone Strikes, N.Y. TIMES, Aug. 11, 2011, http://www.nytimes.com/2011/08/12/world/asia/12drones.html?_r=1\&pagewanted =print, archived at http://perma.cc/YY2U-STAH.

161. See Bergen \& Tiedemann, supra note 46. 
against the quantum of civilian casualty is performed, would the right to targeted killing still exist? What if, indicative assessment signals a civilianto-combatant ratio higher than $25: 1,{ }^{162}$ could we still operate in a right to kill framework under IHL?

Looking through the prohibitory lens of the proportionality doctrine would remind us of article 51(5)(b)'s caution against state attacks such as those that "may be expected to cause incidental loss of civilian life, injury to civilians, damage to civilian objects, or a combination thereof, which would be excessive in relation to the concrete and direct military advantage anticipated."163 Targeted killing in the hypothetical Waziristan scenario above would certainly violate this provision. Articles 57(2)(a)(iii) ${ }^{164}$ and $57(2)(b)^{165}$ provide similar admonition within the context of precautionary measure. Taken together, these two articles provide supervisory oversight over a broader continuum of military activities with explicit focus on minimizing indiscriminate loss of civilian lives. Despite the authoritative provisions of these articles, some commentators challenge AP I's implied constraint on United States forces precluding them from exercising their derivative rights to targeted killing in most circumstances. Contrary to this view, AP I and its progeny statutes' non-binding status with non-state actors do not immunize states from compliance. ${ }^{166}$ Moreover, legal constraints upon states stem from both customary international law as well as AP I and its progeny articles.

While textual interpretation remains a viable force in locating rights within international law, development of customary norms after significant world events often introduce lack of synchronization between theory and

162. Reports indicate that US is killing civilians at the rate of fifty per one intended target. See Kilcullen and Exum, supra note 14. Some research put that percentage somewhere around thirty. See Cyril Almedia, Civilian Deaths in Drone Attacks: Debate Heats Up, DAwn.com, May 9, 2005, http://archives.dawn.com/archives/44038, archived at http://perma.cc/CXW7-MTLC.

163. See AP I, supra note 156, art. 51(5)(b).

164. AP I, supra note 48, art. 57(2)(a)(iii).

165. AP I, supra note 48, art. 57(2)(b).

166. Development in international law in the context of the customary law's provisions of Common Article 3 would imply that, State's obligation under IHL may not necessarily derogate, as it has been reflected in article 6 of Additional AP II with respect to NIAC that meets the requisite threshold. Author Pejic notes:

[Article 75 of Additional Protocol I.] is a fundamental guarantee of human rights law of both a binding and a non-binding nature ('soft law') ... A State party may derogate from (modify) its obligations under those provisions of the treaty under very strict conditions, one of which is the existence of a public emergency threatening the life of the nation. While armed conflict is an example of such a public emergency, it is important to note that measures derogating from States' obligations under the ICCPR may 'not (be) inconsistent with their other obligations under international law.

Pejic, supra note 57, at 211-12 (alterations added). 
practice. The proportionality doctrine relies on a balancing test that measures both the quantum of force and the quantum of derived military advantage. Yet, flawed interpretations of this balancing test have been injected after the two recent major military campaigns by the US and coalition forces, causing divergence between law's intent and state's action. ${ }^{167}$ This balancing test is designed to determine whether applied force runs afoul of inherent doctrinal constraints by measuring the response attack against such attack's "concrete and direct military advantage anticipated." 168 Here, the structural difficulty comes from the fact that identification of the right to attack under the test turns on quantifying a set of imprecise qualifiers like "concrete," "direct," "anticipated" and "advantage." 169 Even if quantification for the test's application is achieved, measuring its precision in asymmetric warfare relies on a set of functional assumptions. For example, asymmetric warfare in the twenty-first century thus far has progressed mainly on two fronts. The two adversaries in the first consisted of a military superpower like Russia, the United States, or Israel on one hand, and a smaller state, breakaway republic, or occupied territory on the opposing end. ${ }^{170}$ The second and the most prolonged

167. I draw attention to the expanded military paradigm enjoyed by the US forces since 9/11. The question of extrajudicial killings, working outside of acceptable norms of international law has been well documented. For context specific to balancing HRL's proportionality principle, see Collateral Damage, supra note 36, at 690.

168. See Frits Kalshoven, Implementing Limitations on the Use of Force: The Doctrine of Proportionality and Necessity, 86 AM. SoC'Y INT'L L. Proc 39, 44 (1992).

169. In the storied history of the modern Laws of War, perhaps no other movement can better capture the humanitarian dimension of the Nuremberg Trials than the formalized incorporation of the principle of necessity. Scholars have both discussed the development of necessity doctrine and its continued difficulty in modern times. See Id. at 40-45; see also The United States Army/Marine Corps Counterinsurgency Field Manual 247-49 (2007) (discussing the principles of distinction and proportionality in the context of war on terror). However, with the advent of modern weaponry, military operations during times of armed conflict have undergone substantial changes over the last sixty years, which have resulted in confusion regarding the proper definition and application of military concepts, such as the concept of military necessity. For example, military planners and human rights organizations disagree about both the fundamentals and the interpretation of military necessity and, consequently, their understandings have diverged. State complicity in abiding by the HRL standards of necessity has made assessment of collateral damage and the determination of culpability of crime problematic. On one hand, necessity in HRL requires States to evaluate whether targeted killing will achieve the goals of the military operation and is in compliance with the other rules of HRL. States on the other hand, invoke right to self-defense without fully being accountable. Legal principles on State responsibility make abundantly clear that States may not invoke self-defense as justification for their violations of HRL. Int'l Law Commission [ILC], Draft Articles on State Responsibility, at 166-7, A/56/10 (2001).

170. For conflicts involving Israel, see AMNESTY INT'L, supra note 25. For conflicts involving Russia, see Russia 'Kills' Chechen Warlord, BBC News, Apr. 25, 2002, http://news.bbc.co.uk/2/hi/europe/1950679.stm, archived at http://perma.cc/6MTZ-W86D. 
hostilities thus far have been those between the United States and non-state actors like Al-Qaeda or Al-Qaeda in the Arabian Peninsula. ${ }^{171}$ When the balancing test of proportionality is applied in these cases, functional assumptions become inherently a product of partial and partisan interests of battlefield commanders. ${ }^{172}$ This observation has been tested time and again in recent years with catastrophic consequences for civilians. ${ }^{173}$ More importantly, because measuring the outcome of the balancing test is inherently predicated on assessing parameters related to the decision making of the commander, the results have been the creation of incoherent jurisprudence on IHL's proportionality doctrine.

After the NATO bombing of Yugoslavia in $1999,{ }^{174}$ the review committee in its final report to the prosecutor of the ICC provided a set of parameters to further calibrate the balancing test of proportionality. ${ }^{175}$

171. See BBC supra note 70; AUMF, supra note 70; GIULIANO, supra note 71 and text accompanying notes 70-72.

172. I draw attention to the facts, or lack thereof, on the ground that may impact the true test of proportionality of necessity, where the assessment by the battlefield commanders are increasing being given deference to in testing the military necessity against civilian casualties.

173. See generally Collateral Damage, supra note 36 (noting military exigencies articulated by commanders on ground has been successful in circumventing the prohibitory frameworks of laws of war resulting in killing innocent civilians).

174. See James Bovard, Kosovo Déjà Vu, FreEdom DAIly (July 2003), http://www.fff.org/freedom/fd0307d.asp, archived at http://perma.cc/7BDJ-VYGS. An American pilot bombed a passenger train on a railway bridge on April 12, 1999, killing fourteen people. Id. NATO's supreme commander, General Wesley Clark said:

[W]hen all of the sudden, at the very last instant, with less than a second to go, he caught a flash of movement that came into a screen and it was the train coming in. Unfortunately, he couldn't dump the bomb at that point. It was locked, it was going into the target and it was an unfortunate incident which he and the crew and all of us very much regret.

Id. However, the public later learned from the Frankfurter Rundschau in 2000, that the video of the passenger train bombing was played on television at triple the speed of the real time video, making the bombing of the train appear more "inevitable" than it truly was. $I d$. For discussions on reports from the review committee, see FINAL REPORT TO THE PROSECUTOR BY the Committee Established to Review the NATO Bombing Campaign Against the Federal RePublic of Yugoslavia para. 49, (8 June 2000), archived at http://perma.cc/CB4R-Z9XU [hereinafter FinAL REPORT to THE PROSECUTOR].

175. See Final Report to the Prosecutor, supra note 174, paras. 45-54; see also Michael Bothe, The Protection of the Civilian Population and NATO Bombing on Yugoslavia: Comments on a Report to the Prosecutor of the ICTY, 12 EUR. J. INT'L L. 531, 534 (2001); Thomas M. Franck, On Proportionality of Countermeasures in International Law, 102 AM. J. INT'L L. 715, 735-36 (2008). Author Robert Barnidge believed the report:

[A]ttempted to provide some general parameters to these and other questions related to the proportionality balancing test. It did this by collapsing the heavy burden of decision making on the shoulders of the "reasonable military commander." At the same time, however, it acknowledged that the decision maker's values, background, education, and combat experience will likely 
Justifying the reasonableness of a military commander's decision through a set of value-laden parameters, this report has shifted the proportionality test from a more precise objective framework to a subjective paradigm, ${ }^{176}$ which is vulnerable to manipulation by political forces. Interpretation of the Rome Statute by the ICC's Chief Prosecutor in the aftermath of the Iraq War may have further diluted the full force of the proportionality principle. ${ }^{177}$ Article $8(2)(\mathrm{b})(\mathrm{iv})^{178}$ of the Statute examines proportionality of an "attack on military objective" by balancing "incidental civilian injuries" against "anticipated military advantage." 179 The Rome Statute would grant a right of targeted killing as long as accompanied civilian injuries can be established as not "clearly excessive" $" 180$ in relation to military advantages to be derived thereof. The Chief Prosecutor's observations in 2006 in response to allegations of war crimes perhaps best capture the deliberate erosion of the proportionality doctrine via politicization of IHL: "Under IHL and [the] Rome Statute, the death of civilians during an armed conflict, no matter how grave and regrettable, does not in itself constitute a war crime.",181

If we were to go by the Chief Prosecutor's observation, it would be rather straightforward to legitimize the act of targeted killing as each one of the incidents can be proven to be both conducted under armed conflict and to have secured a military advantage. However, this observation is fundamentally flawed for the following reason: any loss of civilian life can be supported by employing a loose and expanded interpretation of the Rome Statute on grounds of military advantage. Thus, even the most expansive reading of the Rome Statute can support the decoupling of civilian deaths from consideration as shown above. Moreover, since bias in such prosecutorial observation is provable, it presents a structural impediment for the continued significance of the ICC. Commentators have correctly noted this disturbing trend in IHL, by pointing out the law's

\footnotetext{
influence what can conceivably be considered excessive, or less than, or perhaps even just not quite, excessive.

Barnidge, supra note 25 (alteration added).

176. See Barnidge, supra note 25.

177. See Luis Moreno-Ocampo, The Office of the Prosecutor of the International Criminal Court, The Hague (2006), available at http://www2.icc-cpi.int/NR/ rdonlyres/F596D08D-D810-43A2-99BB-

B899B9C5BCD2/277422/OTP_letter_to_senders_re_Iraq_9_February_2006.pdf.

178. Id. For textual interpretation and discussion of the Rome Statute, see Rome Statute of the International Criminal Court, U.N. Doc. A/CONF. 183/9 art. 8(2)(b)(iv) (July 17, 1998), archived at http://perma.cc/3WUU-MWNU [hereinafter U.N. Doc. A/CONF. 183/9]; See also William A. Schabas, An Introduction to the International Criminal Court 127 (Cambridge Univ. Press, 3d ed. 2008).

179. U.N. Doc. A/CONF. 183/9, supra note 178, art. 8(2)(b)(iv).

180. U.N. Doc. A/CONF. 183/9, supra note 178, art. 8(2)(b)(iv); see also Michael N. Schmitt, Precision Attack and International Humanitarian Law, 87 INT'L ReV. ReD Cross 445-56, n. 41 (2005), archived at http://perma.cc/7N7A-G6J9.
}

181. See Moreno-OcAmPo, supra note 177. 
inability to "provide a clear-cut answer," 182 and need for "a common currency of evaluation." 183 Indeed, a right to targeted killing within the context of the IHL law principle of proportionality may not be justified because proportionality "[is] not a recognized rule of the law of war."

Often the state actors involved in targeted killing tinker with the threshold of proportionality in an attempt to craft a scale of response that legitimizes targeted killing. Despite the evolving nature of hostilities, the reference point of appropriate threshold in the context of proportionality must not be allowed to vacillate from conflict to conflict simply to manufacture legitimacy for targeted killing. Moreover, proportionality brings in other legal conundrums to the entire deliberation process for evaluating the legitimacy of targeted killing. First, the framework of targeting without judicial review is structurally untenable for proportionality compliance. Second, the duality between jus ad bellum and jus in bello in dealing with proportionality might render the act of targeted killing unsupportable as an event under law. ${ }^{185}$ Fundamentally, proportionality calls for measuring the response to the initial attack by calibrating it with a specific quantum of force. Balancing a future quantum of attack might be more complicated if we were to measure the proportionality of attack that has not yet occurred but is expected to occur in the future. This introduces a logical anomaly. Application of proportionality calls for measuring a future event based on imprecise information. Any attempt to calibrate a response would be imprecise because neither the quantum of force nor the timing of the future initial attack could be measured with certainty. Constructing an article 51 selfdefense argument under proportionality to validate targeted assassination based on a future imminent threat, is therefore, highly problematic under IHL. Especially in the context of targeted killing via UAVs in Pakistan, Afghanistan and the Arabian Peninsula, as IHL's just ad bellum rules may invite a higher prohibitory threshold than currently being recognized by the responsible state actors.

\section{F. Distinction-Languishing in the Shadow of Military Necessity}

In armed asymmetric warfare, distinction is the final arbiter of life and death. Against a backdrop of a war on terror-focused hostilities landscape, often confounded by a perplexing maze of international law,

182. See Kalshoven, supra note 168 , at 44.

183. Michael N. Schmitt, Faultlines in the Law of Attack in TeSting THE Boundaries of INTERNATIONAL HuMANiTARIAN LAW 278, 293 (S. Breau, \& A. Jachec-Neale, eds., 2006) archived at http://perma.cc/CMZ9-DGH4.

184. See W.J. Fenrick, The Rule of Proportionality and Protocol I in Conventional Warfare, 98 MiL. L. REV. 91, 102 (1982).

185. See Sloane, supra note 124. 
distinction provides the final guarantee of right to life. Undoubtedly, the right to targeted killing must go through a careful deliberation process to satisfy a series of thresholds as has been highlighted in discussion thus far. For example, a progressive series of analyses must determine (i) whether armed conflict exists, (ii) whether the target has been identified as a functional combatant, (iii) whether military necessity has been established, and, (iv) whether a proportionality analysis has been conducted. The right to targeted killing must go through all these evaluations before embarking on carefully distinguishing between civilians and combatants. ${ }^{186}$ Current practices however, do not adhere to the distinction doctrine as can be seen through the surge of recent civilian deaths from state targeted killing attempts.

A major problem within the current practices of targeted killing comes from the states' inability to decouple the three principles of necessity, proportionality and distinction. Oftentimes, these doctrines are subsumed within each other, and many other times, these doctrines are conflated with each other during analysis. Yet, their stand-alone analysis is vitally important in ensuring not only protection of civilian lives but also, in appreciating the scope and significance of these doctrines for their continued viability in IHL. Moreover, distinction is seen to reside at the heart of inquiry surrounding proportionality's balancing test and necessity's granulated approach discussed earlier.

Whether civilians lose immunity by virtue of their proximate relationship with the operational aspect of the conflict is not the specific focus of this inquiry. A broader definition of functional combatant could efficiently eliminate the indeterminacy aspect of any civilian-combatant dichotomy. Therefore, the determination must default to the state's obligation in reliably distinguishing between functional combatant and nonfunctional combatant. Target identification review at this stage becomes an exercise in correctly identifying only the correct half of the binary. Therefore, distinction under IHL might rely on developing a robust model of the functional combatant. Once the model is constructed with sufficient rigor and due diligence, a simplistic determination is theoretically achievable. For example, once we are satisfied with the parameters of the functional combatant, anyone falling outside the definitional framework of a functional combatant could automatically come under the protection from lethal force under the IHL's distinction principle. Targeted killing comes with a heightened obligation for civilian protection under distinction, ${ }^{187} \mathrm{a}$

186. See U.N. Doc. A/CONF. 183/9, supra notes 180-82 and accompanying text.

187. According to the AP I in article 51(2) of the Geneva/Hague Conventions, "[t]he civilian population as such, as well as such, as well as individual civilians, shall not be the object of attack. Acts or threats of violence the primary purpose of which is to spread the terror among the civilian population are prohibited." AP I, supra note 48, art. 51(2) (alteration added). Additionally, Article 52(1) further stipulates that "[c]ivilian objects shall 
requirement that is gradually being written out of the books by states in their recent shift towards developing a more security-centric model of the functional combatant. Once the parameters to define a functional combatant are completed, we are obligated under IHL to protect the non-functional combatant. However, even if a workable model of the functional combatant is achievable in practice, the interaction amongst the three fundamental compliance requirements makes IHL application of targeted killing extremely problematic.

Under the principle of distinction, an attacking state must distinguish between military targets, and non-functional combatants or civilian objects before the attack begins. The distinction principle has been codified in IHL based on AP I's prohibition on indiscriminate attack, an area I have dissected in Section E above. Additionally, I have noted in an earlier work $^{188}$ that, from the three doctrines of distinction, necessity, and proportionality, the doctrine of distinction provides the most support for upholding a right to life - a right that gets further elevated status under HRL discussed later. For example, regardless of interpretation related to proportionality and necessity, correct interpretation of distinction allows for a particular target to be confronted with deadly force. The principle of distinction, therefore, will not support such actions as targeting a functional combatant within a crowded bazaar in Afghanistan, inside a mosque in Yemen or in the midst of a nighttime wedding reception in the tribal region of Pakistan. Similarly, firing remotely controlled Hellfire missiles at civilian dwellings in villages of Waziristan from operational centers

not be the objects of attack." AP I, supra note 48 (alteration added). Similarly, the 1998 Rome Statute of the ICC makes categorical provisions against, "intentionally directing attacks against civilian population as such" or "civilian objects." Rome Statute of the International Criminal Court art. 8(2)(b)(i)-(ii), July 17, 1998, A/CONF.183/9. By the language "civilian population as such," the statute makes careful distinction between damage caused by direct intentional attack or civilians where no military installation in either present, or no military advantage is to be gained from the attack in which, civilian casualties take place by being in the vicinity of the hostilities. The indiscriminate attacks are laden with wanton disregard for civilian lives and, accordingly, should be interpreted as premeditated acts under AP I, and are defined as:

(a) Those that are not directed at a specific military objective;

(b) Those that employ a method or means of combat which, cannot be directed at a specific military objective;

(c) Those which employ a method or means of combat the effects of which cannot be limited as required by this Protocol; and consequently, in each such case, are of a nature to strike military objectives and civilians or civilian objects without distinction.

Id. art. 51(4). Thus, HRL imposes heightened restrictions on distinction between civilians and combatants. For discussion and commentary see Nuclear Weapons Advisory Opinion, supra note 125, para. 78; Vincent Chetail, The Contribution of the International Court of Justice to International Humanitarian Law, 85 INT'L REV. RED CROSS 252, 256 (2003); see also AP I, Commentary, supra note 48, art. 57, para. 2191.

188. Collateral Damage, supra note 36. 
thousands of miles away should be considered violations of IHL under the principle of distinction. The principle of distinction may foreclose any derivative right the state might claim as flowing from its article 51 of the UN Charter's right to self-defense under most circumstances.

Therefore, given the structural difficulties identified in this analysis and as noted elsewhere, ${ }^{189}$ the distinction requirements remain a vulnerable spot for the IHL application of targeted killing. More importantly, discussion thus far does not support a right to targeted killing under the principle of distinction acting alone within the context of hostilities presented here.

\section{TARGETED KILLING FROM A STANDALONE INTERNATIONAL HUMAN RIGHTS LAW ANALYSIS}

If rights in international law are to flow within a multi-dimensional space, each of its dimensions need to be explored adequately to identify a derivative right to targeted killing. Therefore, if a right to targeted killing can be established under IHL, it may not necessitate a distinct HRL analysis. However, analysis thus far indicates a right to targeted killing under IHL is problematic at best and legally impermissible at the worst. Therefore, my inquiry now turns to finding scenarios under HRL that might generate a right to targeted killing. This rights narrative around targeted killing then would prompt us to seek clarity on whether a functional combatant's human rights were ever recognized or even envisioned within the context of HRL. This would require identifying the framework under which a functional combatant's human rights are currently being processed at various stages of deliberations within the context of targeted killing. Understanding the human rights paradigm of targeted killing would allow us to envision a construct where parties with disparate interests can interact, allowing for various rights to emerge within its intended ontological space.

\section{A. Seeking the Right to Targeted Killing in International Human Rights \\ Law}

Several factors prompt us to seek a right to targeted killing under HRL in this phase of the inquiry. First, to summarize from the previous Section's observation and analysis, IHL supervises types of NIAC where at least one state actor is involved such that participation in hostilities is characterized by clearly designated military personnel. This would necessitate bringing the participants to the hostilities within the purview of specific codes of military justice. However, targeted killing is being conducted in types of hostilities where remotely executed missile strikes via

189. Collateral Damage, supra note 36. 
UAV have been the norm. These remote strikes have been approved and operated by either CIA personnel or CIA contractors. ${ }^{190}$ These actors are neither trained in the law of armed conflict nor bound by the Uniform Code of Military Justice (UCMJ). This has several untenable difficulties under IHL. ${ }^{191}$ These actors are neither expected to exhibit fidelity to IHL, nor do they legitimately fall as designated actors under IHL. ${ }^{192}$ Moreover, the history of IHL suggests, no matter how egregious or illegitimate an act might appear on the surface, unless encapsulated within specific identifiable statutes of international law, criminal culpability may not be recognized under legal principles. ${ }^{193}$

Thus, the central inquiry in codifying the right to targeted killing within the framework of international law should now shift to HRL, as it permits specialized circumstances within evolving military scenarios under its lex specialis principle. Other commentators have supported this view of seeking further clarity under HRL:

Persons with a right to take a direct part in hostilities are lawful combatants; those without a right to do so are unlawful combatants. Having a right to participate in hostilities means that the person may not be charged with a crime for using force. CIA operatives, like the militants challenging authority in Pakistan, have no right to participate in hostilities and are unlawful combatants. ${ }^{194}$

190. Author Alston observed:

States must ensure that training programs for drone operators who have never been subjected to the risks and rigors of battle instill respect for international human rights law and adequate safeguards for compliance with it ... the use of drones for targeted killing is almost never likely to be legal. A targeted drone killing in a State's own territory, over which the State has control, would be very unlikely to meet human rights law limitations on the use of lethal force.

See U.N. Doc. A/HRC/14/24/Add.6, supra note 29 (alteration added).

191. See Murray Wardrop, Unmanned Drones Could be Banned, Says Senior Judge, THE TELEGRAPH, July 6, 2009, http:/www.telegraph.co.uk/news/uknews/defence/5755446/ Unmanned-drones-could-be-banned-says-senior-judge.html, archived at http://perma.cc/G8RQA79. In this context, the general prohibition under HRL is against weapons that violate the principle of distinction or cause unnecessary suffering. See PROGRAM On HuMANITARIAN PoliCY AND CONFLICT RESEARCH AT HARVARD UNIVERSITY, COMMENTARY ON THE HPCR MANUAL ON INTERNATIONAL LAW APPLICABLE TO AIR AND MisSILE WARFARE§ C (3) (2009).

192. See O'Connell, supra note 26 and accompanying text.

193. Here I specifically draw attention to the binding nature of HRL, discussed in this Article in detail. See supra Part III B, C.

194. Author O'Connell observes, "CIA operatives, like the militants challenging authority in Pakistan, have no right to participate in hostilities and are unlawful combatants. They may be charged with a crime." O'Connell, supra note 26, at 22. 
Second, as identified in the previous Section, deterministic complexity comes from the bedrock principles of IHL. The parties and actors involved in hostilities must be adequately trained in the complex conceptual norms surrounding the interacting principles of military necessity, proportionality and distinction. This becomes problematic when non-military personnel are instructed by the state to engage in remotely operated UAV strikes on combatants under extrajudicial capacity. ${ }^{195}$ Not only does this conduct run afoul of applicable military principles and laws of war statutes but also might invite war crime investigations if taken to its logical conclusion via chain of causation.

Thirdly, while jus ad bellum principles of IHL provide guidance on when military activities can be triggered, ${ }^{196}$ jus in bello principles guide us on permissible conducts and behaviors once military actions initiate. ${ }^{197}$ Since the context of our inquiry falls under the purview of NIAC, a paradigm that is in a continuous flux and is subject to periodic review and update, HRL analysis may be more conducive to providing interpretative gloss where IHL analysis has failed to yield a deterministic outcome. Fundamentally, jus in bello sovereignty issues are in conflict with the use of force by a state against non-state actors outside of the state's own territory.

Since targeted killing generally takes place within the active hostilities framework, evaluating the technical elements of the asymmetric warfare must be performed once hostilities have been initiated. This would also allow for an expanded reading into HRL's scope for the discussion of rights. Especially, a combination of jus in bello with HRL's rights-based analysis would keep the trajectory of discussion focused on the need to balance state rights with the combatant-civilian dichotomy within a human rights framework. ${ }^{198}$ This is particularly true when hostilities evolve in confusion. Often this is marked by imprecise distinction between functional combatants and their non-functional counterparts or triggered when parties to the action are conflated with the coexistence of non-state actors with state-sponsored actors. ${ }^{199}$

\section{B. Guiding Principles Illuminating the Rights Discussion}

HRL conduct of hostilities is distinguished from IHL conduct of hostilities in that HRL applicability comes with a higher threshold of state obligations in conducting hostilities. ${ }^{200}$ This is in part because more bulwark

195. O'Connell, supra note 26, at 22.

196. See Sloane, supra note 124 at 49.

197. Sloane, supra note 124 at 49.

198. Sloane supra note 124 at 49.

199. Here I draw attention to the escalating problem of distinction caused by over expanding the definition of combatant, discussed thoroughly in this Article.

200. See, e.g., Armed Activities on the Territory of the Congo (Dem. Rep, Congo v. 
principles have been codified within HRL with the explicit aim of minimizing casualties and protecting human lives. ${ }^{201}$ These principles flow out of HRL's explicit recognition that, as conflicts become more asymmetric, the potential for the unconventional and non-state actors to suffer casualties increases. ${ }^{202}$ On the surface, it might be difficult for a state to overcome HRL's fundamental recognition of the sanctity of life as this explicit promise of inherent right to life is in conflict with the state's derivative right to targeted killing. This is evident from HRL providing a higher threshold of civilian protection than IHL in asymmetric conflict. The recent International Committee of the Red Cross ("ICRC") guidance corroborates such viewpoint:

In classic large-scale confrontations between well-equipped and organized armed forces or groups, the principles of military necessity and of humanity are unlikely to restrict the use of force against legitimate military targets beyond what is already required by specific provisions of IHL. The practical importance of their restraining function will increase with the ability of a party to the conflict to control the circumstances and area in which its military operations are conducted, and may become decisive where armed forces operate against selected individuals in situations comparable to peacetime policing. In practice, such considerations are likely to become particularly relevant where a party to the conflict exercises effective territorial control, most notably in occupied territories and noninternational armed conflicts. ${ }^{203}$

Such restraint espoused by HRL should fundamentally guarantee that

Uganda), 2005 I.C.J. 168, 216 (Dec. 19); Nuclear Weapons Advisory Opinion, supra note 125; Construction of a Wall, supra note 125, para. 106; THE MANUAL ON THE LAW OF NONINTERNATIONAL ARMED CONFLICT, supra note 29 (discussing the guidance provided in contemporary legal manuals and case laws).

201. See E/CN.4/2006/53, supra note 29, ๆๆ 28-29; E/CN.4/2005/7, supra note 29, q9 71-74. ICRC guidelines prescribe a set of norms to prevent civilian casualties and minimize excessive loss of lives. See ICRC Rules, supra note 158, at 521. Author Melzer notes: "Feasible precautions are those precautions which are practicable or practically possible taking into account all circumstances ruling at the time, including humanitarian and military considerations." MELzER, supra note 75, at 365. Significantly enough, in its 2009 interpretative guidance on direct participation in hostilities (DPH), the ICRC has introduced new terminology for members of non-State actor involved in hostilities, members of an organized armed group with a CCF. NiLs Melzer, InT'L Comm. RED Cross, INTERPRETIVE Guidance on the Notion of DiRect Participation in Hostilities under InTERnational HumANITARIAN LAW, 75-76 (2009) [hereinafter InTERPRETATIVE GUIDANCE], archived at http://perma.cc/4EQU-6NVE.

202. See INTERPRETATIVE GUIDANCE, supra note 201, at 74.

203. INTERPRETATIVE GUIDANCE, supra note 201, at 80-81. 
there is no unlimited choice by state actors to inflict casualties. On its face, this must foreclose most means of assassination without judicial due process. How could the state, therefore, still acquire the right to targeted killing within the context discussed thus far?

HRL's focus on the inherent right to life informs us of a broader and expanded obligation to restrict states from engaging in lethal force even when article 51 of the UN Charter is triggered. ${ }^{204}$ Two significant observations follow from this principle. First, HRL's framework places a much higher burden on states for application of proportionality, which would require developing an appropriate balance between achieving military objective and minimizing excessive (disproportionate) loss of civilian lives. This will require conducting drone strikes with such precision that disproportionate loss of civilian lives must be eliminated in most cases. ${ }^{205}$ This places a heavy burden on both intelligence gathering and target selection; however, ground intelligence cannot reliably determine the proximate surroundings of an individual target, ${ }^{206}$ nor has it been possible to precisely determine the coordinates of a high value functional combatant. Yet, the drone strikes are being advertised as causing minimal collateral civilian damage. ${ }^{207}$ However, reality tells a different story, for reasons highlighted below.

Evidence suggests that missile strikes via UAVs have killed a disproportionately large number of individuals compared to the intended single individual or the handful of individuals being targeted. ${ }^{208}$ Despite

204. See Nuclear Weapons Advisory Opinion, supra note 125, ๆๆ 38-42.

205. U.N. Doc. A/HRC/14/24/Add.6, supra note 29 states:

This means that under human rights law, a targeted killing in the sense of an intentional, premeditated and deliberate killing by law enforcement officials cannot be legal because, unlike in armed conflict, it is never permissible for killing to be the sole objective of an operation. Thus, for example, a "shoot-tokill" policy violates human rights law. This is not to imply, as some erroneously do, that law enforcement is incapable of meeting the threats posed by terrorists and, in particular, suicide bombers. Such an argument is predicated on a misconception of human rights law, which does not require States to choose between letting people be killed and letting their law enforcement officials use lethal force to prevent such killings. In fact, under human rights law, States' duty to respect and to ensure the right to life entails an obligation to exercise "due diligence" to protect the lives of individuals from attacks by criminals, including terrorists. Lethal force under human rights law is legal if it is strictly and directly necessary to save life.

U.N. Doc. A/HRC/14/24/Add.6, supra note 29, ๆ 33; See also E/CN.4/2006/53, supra note 29, ๆๆ. 44-54; E/CN.4/2005/7, supra note 29, ๆ甲 71-74; International Covenant on Civil and Political Rights, G.A. Res. 2200A (XXI), 21 U.N. GAOR Supp. No. 16, 52, U.N. Doc. A/6316, art. (II)(1) (Dec. 19, 1966), entered into force Mar. 23, 1976.

206. See sources cited supra notes 102, 104 and accompanying text.

207. See supra note 3.

208. See supra note 3. 
having the most sophisticated technology and precision-guided weapons, it has been virtually impossible to either effectuate a "clean surgical kill," or, minimize the loss of civilian lives, while targeting functional combatants in crowded neighborhoods and dwellings. Evidence further indicates that most of the strikes since 2002 have taken place in crowded dwellings, inside dwellings shared by children, elderly, and sick people, in public transport vehicles and in cars with multiple occupancy. ${ }^{209}$ But, there is lack of reliable information. Due in part to inaccurate evidence on the ground, and due in part to absence of transparency associated with such operations. As a result, the relative proportions of functional combatants and civilians killed in remote UAV strikes cannot be reliably evaluated. Although the HRL's proportionality principle does not provide a specific ratio of combatant to civilians, evidence uncovered thus far presents some disturbing trends in recent drone strikes. First, a disproportionate number of the old, infirm, and children have been killed, ${ }^{210}$ in direct violation of HRL's proportionality principle's "qualitative" aspect of the balancing test. ${ }^{211}$ Second, if statistics on drone strikes of the last few years are compiled, it might establish that in most of these instances, less than 10 percent of the killed individuals would be deemed functional combatants under the most expansive definition of the term. ${ }^{212}$ Thus, recent targeted killings do not comport with the HRL principle of proportionality.

Sanctity of human life is one of the animating principles of HRL. Thus, locating a right to targeted killing under HRL would require balancing such rights with an inherent right to life. In this evaluation, right to kill a suspected terrorist would flow from the savings gained from a targeted strike in preventing even bigger damage. This savings has to be balanced against a proportionality that compares the harm caused after the targeted strike. Moreover, the right to life analysis cannot be regionalized or made target-specific, as all civilians regardless of the geography should have the same right to life. Unfortunately however, some scholars have taken this "inherent right to life" doctrine to construe an isolated right to life for American citizens in order to carve out an exclusive right to targeted killing of suspected terrorists. ${ }^{213}$ Such analysis would be fundamentally

209. See Collateral Damage, supra note 36.

210. See Collateral Damage, supra note 36.

211. See sources cited supra notes 3,46 , and accompanying text.

212. For any strike to have a percentage of combatant kill to be above $10 \%$ of all kills, this would require the ratio of combatants to civilians killed in the battlefields of Pakistan, Afghanistan and the Arabian Peninsula to be below 1:10. On the basis of available data and corroborative evidence, it is clear that such ratio is significantly higher than 1:25 in relative abundance of civilian deaths.

213. Prohibition against deprivation of life without due process of law is a bedrock principle of the American Constitution, enshrined in its Fifth Amendment. If this is taken to its logical extension and used as a precondition for protection against imminent threat to the US and doing anything to prevent such losses of lives can trigger both a self-defense right 
flawed under HRL.

At the minimum level, a right to targeted killing emanates from a selfdefense right against imminent threats to other lives. A fully transparent and legally robust targeted killing framework would, therefore, call for an authentic evaluation of all concomitant factors when a target is identified in the battlefields of Pakistan, Afghanistan, or in the Arabia Peninsula area (for example, Yemen or nearby Somalia). For Americans, the conflict between imminent threat and the right to self-defense are influenced by factors, such as, the remoteness of the physical location, the actual geographical boundaries of the continental United States, and the weapon delivery mechanism available to the suspected terrorists. It can be argued, in a majority of the situations, the attack against American citizens is at best plausible, but far removed from being possible. For this plausibility to have a remote chance of success a set of definitive pathways must be identified and their chances of success have to be evaluated. Yet, such remotely plausible events are being recognized as definitive in order to construe a right to targeted killing by the state. Such instances of using a logical extreme to satisfy compliance requirements of a limiting case must be recognized as not only legally impermissible, but highly deceptive to have any legitimacy within HRL. It must be recognized that, the inherent right to life is not an exclusive right preserved only for some citizens, as this right to life places both a prohibitive barrier and an insurmountable threshold for application under HRL for all citizens of the world.

\section{Proportionality, Distinction, and Military Necessity in International Human Rights Law}

A comprehensive inquiry seeking a derivative right to kill cannot be completed without discussing HRL's focus on proportionality in the context of lex specialis. As per the ICRC guidelines, respect for civilian status must be the illuminating principle in determining strategies for conducting military hostilities, including identifying and targeting for the assassination of suspected terrorists. ${ }^{214}$ A presumptive civilian status rule must therefore be read into the analysis of the HRL's proportionality principle. ${ }^{215}$ The

and the ability to use force to prevent harm to life. However, this causal chain of reasoning is fraught with multiple conditions that cannot be adequately evaluated and thus fulfilled deterministically for the argument to have any force.

214. See, e.g., Int'l Comm. of the Red Cross, Committee of the Red Cross in the Event of Violations of International Humanitarian Law or of other Fundamental Rules Protecting Persons in Situations of Violence, 87 INT'L REV. OF THE RED CROSS 858 (2005).

215. Presumptive civilian status has been codified in jurisprudential development of international humanitarian rights law. "Persons taking no active part in the hostilities, including members of armed forces who have laid down their arms and those placed hors de combat by sickness, wounds, detention, or any other cause, shall in all circumstances be treated humanely . . . Convention IV, supra note 45, art. 3 (emphasis added) (alteration added); Convention II, supra note 45, art.3; Convention III, supra note 45, art. 3 (emphasis 
ICRC guidelines would suggest applying a presumptive civilian status to all persons during hostilities at the onset of evaluation. Therefore, prior to determination, all individuals must be recognized as having either a civilian or a non-functional combatant status. ${ }^{216}$ Any change in status to a functional combatant would then be done through actual and verifiable evidence. Such comparatively heightened civilian protection in HRL comes from a set of significant observations. First, in asymmetric conflict, civilians are thoroughly unmatched compared to the dominant party's available firepower. Second, characterizing a functional combatant for the purpose of targeting is difficult in the NIAC context.

Applying a presumptive civilian status to all participants would then allow for a narrower definition to become operationalized for functional combatant status review. Thus, by changing the targeted killing framework from IHL to HRL, civilian deaths could be reduced significantly. Given the escalation of disproportionate civilian deaths in the current asymmetric hostilities, this is a much-needed framework. Not only would such a bulwark prevent the continuous orgy of civilian killings, it might ultimately find it difficult to legitimize states' right to targeted killing.

Unfortunately, the ICRC's presumptive civilian status guideline has remained as such - a guideline without much binding power for widespread implementation. Adherence to this guideline has neither been followed nor given any practical validity from state policy perspectives, especially states engaged in targeted killing. In the end, however, HRL's recognition of inherent right to life provides a much difficult threshold for UAV-based targeted killing to overcome.

\section{Necessity in International Humanitarian Rights Law}

An analysis of targeted killing under HRL cannot be completed without a nuanced analysis of the necessity doctrine, especially in light of the recent work by Niels Melzer. ${ }^{217}$ By introducing a component level granulation of the broader necessity principle, Melzer attempted to develop a more robust HRL paradigm. ${ }^{218}$ Some of the granular aspects of his

added); See also AP I, supra note 48, arts. 47, 67.1 (regarding the definition of mercenary and dealing with civil defense, respectively). By the customary international law principle of proportionality, reflected in articles 51.5(b), 57.2(a)(iii), and 57.2(b) of AP I, "an attack which may be expected to cause incidental loss of civilian life, injury to civilians, damage to civilian objects, or a combination thereof, which would be excessive in relation to the concrete and direct military advantage anticipated" is prohibited. AP I, supra note 48, art. 51.; See also United Kingdom Ministry of Defense-Joint Doctrine And Concepts Center, The Joint Service Manual On The Law Of Armed Conflict $\S 5.3 .2$ (2004) [hereinafter JoInt SERVICE MANUAL] archived at http://perma.cc/K7TW-QUPW.

216. JoInt Service MAnual, supra note 215; Convention II, supra note 45, art.3; Convention III, supra note 45, art. 3.

217. See Melzer, supra note 75, at 227-230.

218. See MELZER, supra note 75, at 227-230. 
proposed framework have already been elaborated on by other commentators elsewhere. ${ }^{219}$ My review of Melzer's analysis, therefore, would focus on issues that may not have been addressed before, yet, might help us in locating a right to kill within the HRL space. Teasing out the qualitative and the quantitative dimensions of necessity might represent an elegant way of determining whether an engaging state has satisfied the HRL criterion for article 51 of the UN Charter's right of self-defense. However, from the implementation perspective, such granulated distinction may still give a state the right to targeted killing. For example, Melzer's qualitative necessity would not prevent the United States from targeting Baitullah Mehsud on the ground in Waziristan using the least-harmful means test. This is because the alternatives of capturing him alive via ground forces, or immobilizing him via different types of weapons is hopelessly "ineffective or without any promise of achieving the intended result." 220 Similarly, Melzer's quantitative necessity would not necessarily prevent the killing of a suspected terrorist by a Hellfire missile from an American drone, since the quantitatively lesser threshold of violence cannot be applied here. In such an instance, the relevant American commander may not agree on either disengaging or, attempting to immobilize the target by anything less than the quantum with fatal consequence. Thus, while these doctrines are elegant from a theoretical framework, they lack any meaningful bulwark against random civilian death and therefore, fail to comport with HRL's right to life principle.

Melzer has proposed a temporal necessity that imposes a heightened standard of imminence requirement for the purpose of targeted killing. ${ }^{221}$ This is significant, as the commanders on the ground in current hostilities with Al-Qaeda or Al-Qaeda in the Arabian Peninsula use a relaxed threshold that uses a much broader timeframe to determine what is an imminent threat. An elevated threshold of imminence would restrict such commonly used application by fixing a quantum of temporal window for conducting targeted killing. In this context, some scholars have espoused a more relaxed targeting framework, mostly in order to legitimize the state's objective by interpreting that, targeting may be legitimate under HRL up until the very moment of the lethal force's application. This provision would allow for the exigent scenarios to evaporate just immediately before the actual and intended strike. However, the paradigm would create delineation problems between when it is not yet and when it is no longer absolutely necessary to achieve the desired purpose in cases of exigencies. $^{222}$ Reading a strict imminence standard to this requirement

219. See Chesney, supra note 51, at 54-57.

220. UN Basic Principles, supra note 140, 44.

221. See Melzer, supra note 75.

222. Chesney, supra note 51, at 54. 
invites real problems in satisfying HRL requirements in scenarios involving credible threats of terrorism during hostilities. This is because a strict imminence version views a potential target as an executioner within temporal proximity. Moreover, it does not take into consideration the target's ability as the coordinator and planner of an operation. In this strict imminence sense, Baitullah Mehsud in our example could not be a legitimate candidate for targeted killing. ${ }^{223}$ Rejection of this strict imminence model because of impracticability prompts us to a default discussion on a more relaxed version of imminence.

Some might argue that, impractical restriction of imminence calls for a more relaxed interpretation to adequately place the necessity doctrine in the HRL context, more specifically, to trigger article 51's self-defense. Toying with the imminence threshold could, however, be self-defeating. If the more restricted version of imminence suffers from impracticality, a more relaxed version would suffer from a lack of transparency within current asymmetric warfare. For example, when a state invokes the HRL's necessity doctrine under non-strict imminence, there is virtually no guarantee that conditions conducive to such imminence actually exist. Scholars have attempted to overcome this doctrinal weakness of factual uncertainty by introducing an exigency consideration under the "last window of opportunity." 224 However, placed against the more fundamental strand of "right to life" doctrine of HRL, this weakness of factual assumption creates an insurmountable barrier for the necessity doctrine to prevail over imposition against acquiring a right to targeted killing.

223. See generally Mayer, supra note 46 (describing the targeted killing of Mehsud).

224. As I have noted in this Article, legal scholarship surrounding targeted killing seem to be diverging along two distinct stands. Proponents who espouse an expanded conception of State's right who finds a broader right to kill within the legal firmament. One such scholar crafted a legal reasoning for targeted killing posited on the last window of opportunity, even if the certainty for threat may be questionable. He notes:

[T] argeting of suspected terrorists must be restricted to cases in which there is credible evidence that the targeted persons are actively involved in planning or preparing further terrorist attacks against the victim state and no other operational means of stopping those attacks are available. As there is always a risk that the persons attacked are not in fact terrorists, even in such a case lethal force may be used against the suspected terrorists only when a high probability exists that if immediate action is not taken another opportunity will not be available to frustrate the planned terrorist attacks.

Kretzmer, supra note 27, at 203 (alteration added). Some scholars do not explicitly mention such window to propagate a theory of killing, however, attempts to straddle the contour of a right to kill based on international humanitarian rights law's human rights protection doctrine structured via the lost opportunity to save lives. See, e.g., Michael N. Schmitt, US Security Strategies: A Legal Assessment, 27 Harv. J. L. \& PUB. PoL'y. 737, 756 (2004). 


\section{E. Military Necessity Based on Imminence Within International Human Rights Law}

Principles of distinction and proportionality are more intricately linked to HRL application, as long as we can adequately immunize from the conflation problem. HRL's restriction on force is further legitimized by the structural connectivity between proportionality and distinction evidenced in a manner manifested by each of these principles which seem to be enhancing the force of the other. In essence, they emanate from each other. There is an inherent dichotomy with the parameters of twenty-first century warfare. The act of war is conducted with highly sophisticated technology, capable of delivering disproportionately asymmetric firepower to the enemy on the ground. On the contrary, ground intelligence and theater of operation are marked by unreliable human intelligence, ${ }^{225}$ unfriendly terrain, ${ }^{226}$ and unsophisticated delivery mechanisms. ${ }^{227}$ All of these characteristics render the process of reliable determination of the functional combatant difficult, if not impossible. Therefore, when reliable distinction between functional combatant and its binary equivalent of non-functional combatant is unavailable, the proportionality analysis must be conducted with enhanced due diligence. If the proportionality factor is determined to be unreliable or rendered insignificant, eliminating or reducing civilian casualties is highly probable. Thus, by conducting a proportionality analysis, military planners can develop a buffer against human error, thereby reducing human casualties, objectives that are inherent to the animating principles of HRL framework.

Now turning the focus to HRL's necessity and imminence principles, I am concerned with the contemporary tendency to construe a right to targeted killing from an illegitimate analysis. Some analysis has taken the imminence requirement and structured a more conducive scenario for targeted killing, without carefully processing the evidentiary concerns, distinctive principles, and remoteness of connections, any one of which could render targeted killing under IHL difficult. In this context, Melzer's granular approach in articulating the necessity doctrine into three separate constituent elements may be a more promising possibility. ${ }^{228}$ Although the "temporal" necessity requirement provides a much more prohibitive bar, attempts have been made to use temporal necessity for legitimizing targeted killings under the framework of the "last window of opportunity." 229

225. See sources cited supra notes 102, 104, and accompanying text.

226. See Stephanie Carvin, The Trouble with Targeted Killing, 21 SECURITY STUdIES 3 (2012).

227. Id. at 3-4.

228. See MELZER, supra note 75.

229. See Michael N. Schmitt, Preemptive Strategies in International Law, 24 MicH. J. INT'L. L. 513, 534-36 (2003). 
However, this last window of opportunity model does not follow from the fundamental tenets of IHL's inherent right to life. Yet, it is an elegant construction developed by the need to legitimize targeted killing of combatants within the current continuum of hostilities.

Ultimately, even HRL on a standalone basis cannot fully provide legal legitimacy for targeted killing. Thus, neither taking its constituent principles separately, nor combining them may provide international law with a meaningful paradigm to allow states' right to targeted killing.

\section{IS THERE AN EVOLVING PARADIGM FOR THE RIGHT TO TARGETED KILLING?}

If either IHL or HRL acting alone could legitimize a right to targeted killing, perhaps no further inquiry would have been needed at this stage. Nonetheless, as I have identified in the preceding sections, finding a legitimate right within international law may be problematic under both IHL and HRL. Seeking such a right within the larger manifold of international law, I now examine the hybrid strands constructed out of both IHL and HRL. Although there have been instances where either the IHL or the HRL may apply in incorporating some elements at isolated phases of either the NIAC, or in the IAC, it would be instructive to evaluate whether taken together they could construct a legitimate right of targeted killing for all instances.

\section{A. Locating the Right to Targeted Killing Within Shared IHL/HRL Space}

Ultimately, whether operating stand-alone or evolving within the hybrid IHL-HRL context, right to life is in existential conflict with the right to targeted killing. Tracing the origin of these doctrines could shed light on their dichotomy. As a doctrinal development, right to life emanates spontaneously from distinct threads of settled international law. On the contrary, right to targeted killing is a geopolitical derivative of unilateral state action that has never been intended as part of customary international law. Right to targeted killing can best be recognized as a derivative right that must be acquired through interactions of rights and events. Thus, to exist within the framework of international law, at a basic minimum, the right to targeted killing must satisfy the basic fundamentals of necessity, proportionality, and distinction. In this narrative of rights' adequacy, the combinations of combatant characteristic and hostility types might differ, but the component level analysis of these principles must never lose force for such right to exist in any scenario.

Careful analysis of various hybrid scenarios containing parameters of IHL and HRL must be put through various threshold tests. Even by stretching the limits of our imagination and relaxing the thresholds of imminence and proportionality, a right to targeted killing within the shared 
manifold of IHL-HRL seems to suffer from existential difficulty. Thus, rejection of such rights now prompts us to seek sanctuary within domestic developments of law, for which, the analysis would turn on determining whether the combination of domestic US law foundation, and existing strands of international law together could provide justification for targeted killing. ${ }^{230}$

\section{B. Can The US Domestic Law Extend to a Right to Self-Defense?}

President Bush's September 18, 2001 Authorization for the Use of Military Force (AUMF) provided an expanded authorization to use lethal force against entities determined by the President to have been responsible for the 9/11 attacks. ${ }^{231}$ Presidential authority to use "all necessary and appropriate force" could be interpreted by some as a de facto carte blanche to use any variant of unrestrained and unlimited force including lethal force to selectively target individuals the state recognizes as an enemy. This interpretation suffers from various fatal flaws. First, by engaging in a component level analysis of the AUMF's relevance, intent, and scope, the substantive deficiency of the argument becomes quite apparent. Second, the AUMF's disconnect from the basic tenets of international law makes it inherently incongruent for any application related to targeted killing. Third, the temporal divergence between the AUMF's original invocation and the still continuing hostilities make connection between such Presidential authorization and a right to targeted killing logically untenable.

Indeed, the AUMF triggers the self-defense right under article 51 of the UN Charter, the fruits of which the United States forces have enjoyed all too well. The important questions are: whether the AUMF is still applicable more than a decade later? Is there a temporal statute of limitations on such domestic declarations? Or, is it an example of what some scholars characterize as the "laws of 9/11"232 shaping international

230. See infra Section V.B.

231. AUMF, supra note 70. AUMF grants authority for use of United States Armed Forces against those responsible for the attacks on September 11, 2001. By the explicit mandate under the authority of AUMF, signed by President George W. Bush on September 18, 2001, the United States President has full power to use all "necessary and appropriate force" against those whom he determined "planned, authorized, committed, or aided" the September 11th attacks, or who harbored said persons or groups. Clearly, AUMF contained deterministic elements, such as, "all necessary and appropriate," "determined," "full power," all of which could be subject to diverging interpretation. AUMF, supra note 70; see also The Authorization for Use of Military Force Against Iraq, Pub. L. 107-243, 116 Stat. 1498(enacted on Oct. 16, 2002). This was a joint resolution passed by the United States Congress under H.J. Res. 114 which authorized military action against Iraq without United Nations mandate. H.R.J. Res. 114, 107th Cong. (2002), archived at http://perma.cc/FMJ9-A7JN.

232. See Curtis A. Bradley \& Jack L. Goldsmith, Congressional Authorization and the 
jurisprudence? Let us again relax the restrictions for the argument to proceed.

We assume the AUMF has continued sustenance and article 51's selfdefense trigger is valid. To evaluate whether such authorization can fundamentally support targeted killing would require identifying the operating elements of the AUMF and analyzing them for their relevance in creating such a right. This would include interpreting the elements, such as, "all necessary and appropriate force" and entities "responsible for the 9/11 attacks." 233 A quick review would reveal that, the invocation of targeted killing under the operating phrase "all necessary and appropriate force" is highly problematic - fundamentally, legally, and morally. As international law is not based on moral arguments, we can ignore the moral reprehension any attempted statutory connection to targeted killing might produce. On the other hand, international law's fundamentals must certainly be indexed at legally supportable doctrines. This would prompt us to analyze the AUMF's core legal principles to search for a right to targeted killing within the NIAC framework.

First, focusing on the term limit of the AUMF passed in September 2001, we must inquire if there is a sunset provision to such authorization. This is significant, as the AUMF was a response to a specific act and was construed to be under a different scope and context. Can that authorization continue to provide legal legitimacy to trigger article 51's self-defense rights in the current scenarios? Although there has been no discernible legal precedent to support or reject, we can construct our logic by carefully analyzing the antecedent elements. The events on 9/11 were significantly violent. Retaliatory events that followed are no less violent and comprehensive in dehumanizing more people that have been remotely impacted by $9 / 11$. The aftermath has been the subject of much legal debate, and has already given rise to multiple full-scale wars and hostilities that have continued unabated. ${ }^{234}$ Moreover, both the perpetrators and the responsible actors have already been rendered inert and inactive. Any article 51's self-defense trigger to connect targeted killing must therefore be recognized as new and should be framed out of a new reality and consequently, must derive force from a new authorization. Thus, envisioning a right to targeted killing must not be based on the 2001 AUMF and must certainly be based on renewed legal arguments. ${ }^{235}$ Therefore, the AUMF's continued validity should no longer be used for justification of force in the international context, most specifically in IAC or NIAC.

War on Terrorism, 118 HARV. L. REV. 2047, 2068 (2005) (discussing the interpretive relevance AUMF within the context of HRL); see also HoWARD ET AL., supra note 16.

233. See AUMF, supra note 70.

234. See Narrative of Dehumanization, supra note 8.

235. See generally, Chesney, supra note 51 (examining under what circumstances authorization based on AUMF might collapse within the context of targeted killing, while advancing an argument for developing additional legal criteria for such targeted killing). 
Stepping away from the above temporal disconnects and the derived irrelevance of the AUMF, my inquiry now turns to the operating interpretation of "all necessary and appropriate force." 236 The last decade has seen tremendous technological advancement in military capabilities. A powerful state can deliver a much more lethal response to its enemy than it would otherwise have been able to prior to $9 / 11 .^{237}$ A broad interpretation of "all" would significantly expand states' right to use a wider range of weapons, including UAVs and drones. This may not necessarily comport with the intended meaning enshrined in HRL's inherent right to life doctrine. Thus, the meaning of "all" must be restricted to such "all," whose applications are governed by international law. Hostilities conducted in Iraq have clearly uncovered this naked asymmetry in international law. ${ }^{238}$ For example, despite US and British forces using "cluster bombs," 239 the Chief Prosecutor of the ICC was unable to review the allegations involving such weapons owing to the lack of available legal guidelines. ${ }^{240}$ Extending this argument to the applicability in UAVs, the United States should recognize their obligations under HRL and balance the need to apply "all" against prohibitions under law and restrictions on a definitional paradigm.

Further, applying the terms "necessary and appropriate" in an unrestrained manner within the context of a predicated response may be structurally inconsistent with HRL's aspirations. Therefore, usage of such terms should come with appropriate preconditions for an act to be considered "necessary and appropriate." ${ }^{241}$ Moreover, it raises complex questions surrounding the reality of today's asymmetric warfare. Does being a bomb maker living in the remote mountains of the frontier province of Pakistan make one a target to be dealt with "all necessary and appropriate force" under HRL? Given the AUMF's limited applicability in NIAC, HRL's principles must be recognized as the guiding legal framework for rules of engagement. Contextually, the analyses conducted in Sections III and IV should provide the appropriate implementation steps. Moreover, we must recognize in this context, that the AUMF only provides a triggering mechanism. Once that trigger occurs, applicable international law must take over. Therefore, an expanded conception of such

236. See sources cited supra note 70 and accompanying text.

237. Here, I draw attention to the fact that, since 9/11, two parallel developments - one via a predominantly security-centric jurisprudence and, the other, through a product of modern innovation characterized by technological sophistication of military capabilitieshave created structural asymmetry between the actors involved in conflicts. Thus, allowing a more expansive and all-pervasive capability to state actors is tantamount to distort the foundational principles and underlying spirit of international law.

238. See Collateral Damage, supra note 36.

239. Collateral Damage, supra note 36, at 682.

240. See sources cited supra note 174 and accompanying text.

241. See Chesney, supra note 51 (discussing elements related to preconditions of article 51 self-defense). 
authorization must not be construed to provide additional rights beyond what is already available under IHL and HRL. Rather, any legitimacy such authorization might draw must be garnered by juxtaposing laws external to the AUMF in question.

The AUMF inquiry must therefore flow along two foundational strands. First, it must be ascertained how a state can acquire the right to targeted killing from its invocation of the AUMF. ${ }^{242}$ Second, such determination must be based on applicable law surrounding the state's obligation under hostilities the state is engaged in. ${ }^{243}$ Thus, any legal conjecture that the AUMF incorporates IHL or HRL by implication is simply not there. Any construction of derived power under the AUMF, therefore, only comes from conflating the meaning of the authorization within the hybrid strands of IHL-HRL. Rather, the AUMF can be interpreted to provide a proxy for a domestic law authority as an alternative to legislative authorization under the President's war power. In this construction, the authority under the AUMF is better interpreted within the category of presidential power under Article II of the US Constitution, ${ }^{244}$ whereas, the President is allowed a degree of flexibility without legislative authorization. Thus, even if, for argument's sake, we assume that the AUMF triggers a self-defense right, the follow up analysis defaults to a nuanced discussion on IHL and HRL as argued in Sections II, III and IV above.

Thus, the AUMF can provide legitimacy in the use of force only up to the point where it triggers the right to self-defense. Wider implication of the authorization has been erroneously invoked on multiple grounds. First, as I have highlighted here, the AUMF's all necessary and appropriate force characterization cannot function outside of international law, as the authorization can only be used as a triggering principle, which may be more limiting than it is expansive. Second, even restricting the plain language meaning of the $\mathrm{AUMF}^{245}$ would trigger a separate two-pronged inquiry. The first focusing on the mechanism by which the President makes a determination and the second, evaluating on the substantive force of such determination that must conclusively establish that the individual being targeted is responsible for the $9 / 11$ attacks. In an altered geographical

242. See generally Chesney, supra note 51 (examining in detail the continued relevance of AUMF in conducting remote controlled targeted killing and identifying some of the core issues in allowing AUMF to provide authorization for such killings).

243. See supra Section III, IV.

244. See generally Saby Ghoshray, Illuminating the Shadows of Constitutional Space While Tracing the Contours of Presidential War Power, 39 Loy. U. CHI. L. J. 295 (2008) (identifying the various instances of presidential power in war time scenarios).

245. See AUMF, supra note 70; see generally Chesney, supra note 51 (explaining the general framework of how AUMF can be interpreted to provide authorization for targeted killing). 
topography and geopolitical landscape, it becomes logically unacceptable and legally impermissible to assign culpability of $9 / 11$ attacks to all current actors operating in remote locations in Pakistan and the Arabian Peninsula.

Finally, based on available evidence, the majority of the United States targeted killings are being conducted by CIA and CIA contractors ${ }^{246}$ where does the element of presidential determination fall in this scenario? Perhaps, the Supremacy Clause of the United States Constitution ${ }^{247}$ might provide some context to an invocation of domestic law. However, domestic law could only provide a trigger to an external conduct, norms of which ultimately could be governed by existing rules of international law. This supremacy clause has not been invoked until recently in a government brief related to the Al-Awlaki lawsuit. ${ }^{248}$ As this invocation lacks proper construction, it ultimately misconstrues a right to targeted killing by conflating it as a right that derives from international law with a right that is borne out of obligation under the treaty principles. Regardless of the conflation, the argument against a right to targeted killing is grounded on solid legal reasoning, as I have attempted to establish throughout this Article. Even if the Supremacy Clause of the Constitution triggers the article 51 self-defense right, it can go only as far as the Clause's foundational aspiration would allow it to go. Thus, for the right to targeted killing to flow out of a self-defense right, it must arrive via the pathway of a derivative right, for which the only available vehicle would be through the behavioral norms of international law. Based on the arguments presented here, it can be argued, right to targeted killing has not arrived yet within the expanded confines of international law.

\section{CONCLUSION}

This inquiry began with a question - do states have a right to kill suspected terrorists by means of remote controlled operations under international law? The objective of this inquiry has been to locate such a right within the multidimensional manifold of international law. The

246. See Collateral Damage, supra note 36.

247. The text of the Supremacy Clause, contained in Article VI, Clause 2 of the United States Constitution mandates that, the US Constitution, US Treaties, and Federal Statutes, together form "the supreme law of the land." US CONST. art. VI, cl. 2. The text of the Clause mandates that all state judges must follow federal law when a conflict arises between federal law and either the State constitution or State law of any State. Id. The use of the word "shall" in the Clause is noteworthy as it makes it a necessity. Id. Significance can be derived from the inclusion of the phrase "in pursuance thereof," within the Clause which implies that the Supremacy Clause only applies if the federal government is acting in pursuit of its constitutionally authorized powers. Id.

248. See Opposition to Plaintiff's Motion for Preliminary Injunction and Memorandum in Support of Defendants' Motion to Dismiss, Al-Awlaki v. Obama, 727 F.Supp.2d 1 (D.D.C. Sept. 25, 2010) (No. 10-cv-1469(JDB)). 
pathway to seek such a right has been through a rights paradigm. Having carefully researched the existing principles of international law and after evaluating their implications with domestic law's evolution, I have identified significant difficulties in construing such a right.

Targeted killings are state sponsored violent acts that are fundamentally inconsistent with the right to life doctrine. For targeted killing to be recognized as legitimate, the act must be associated with a legitimate right of the state involved in such killings. Therefore, a search for legitimacy in seeking such a right prompted my inquiry into reviewing current guidance, jurisprudence, and emerging scholarship in international law. While my analysis reveals structural weakness and logical inconsistency in supporting a legitimate right to targeted killing in all scenarios, it leaves open some possibilities due to law's inability to catch up with developments on the ground. Yet, questions remain as to whether such possibilities can be justifiably realized.

From a procedural point of view, the possibility remains open simply because more research is needed to fully evaluate the nuances surrounding the unregulated space of international law. From a customary point of view, possibilities exist mostly because the state right to targeted killing has been perilously hijacked by powerful state interests. In the absence of an explicit mandate from established legal principles, states attempt to construe a derivative right to targeted killing from their existential needs codified under the right to exist. As a result, international law's core continues to be distorted through states' faulty constructions of their compliance requirements of proportionality, necessity, and distinction under the hostilities framework. Searching for the right to targeted killing, this Article evaluated the framework behind such state actions.

The post-9/11 landscape has allowed powerful nation states to trample traditional norms of international law in construing their right to targeted killing. A state's violation, however, does not stem from imprecision of text, nor does it emanate from the difficulty in synchronizing theory with practice. Rather, invocation of any right to kill by a state has been the product of incoherent and fractured jurisprudence, generated from the bowels of international law, distorted by political machination of states. Despite international law's promise of equality, its supervisory capability has been diminished in a crowded landscape of players and parties with diverging interests. As nation states jockey for political supremacy, their political origin has been unglued. As the various restraining principles of armed conflicts become weakened, violent norms like targeted killing have claimed a stake for legitimacy. It is within this cacophony of international law's unregulated sphere that the right to targeted killing gains currency for its emergence.

Therefore, a right to targeted killing must be construed within the regulated space of international law, where legal rights are not created in a vacuum. Whenever there is a physical entity or a living entity residing 
within that physical space, legal rights are created. Universally, we can frame legal rights as those that are created whenever a physical space or a living entity is recognized. Therefore, whenever any combination of physical space and living entity is recognized, legal rights are created. These legal rights act as a supervisory framework that define the movement of living entities within the physical space, without taking away the set of inherent inalienable right to which all humans are entitled. So, the focal point of my analysis centered on identifying the nature of physical space and the categories of conflicts that might form the background for a right of targeted killing to evolve.

For targeted killing to be legitimized as an act, therefore, such right has to be envisioned in order for it to be executed. ${ }^{249}$ Any rights discussion, however, would bring ancillary queries. Could we envision a right to targeted killing without conceptualizing a remedy for such rights? Or, could this right to targeted killing automatically evolve from the interacting statutes and case laws that illuminate the vast firmament of international law? In my view, answers to these questions go back to the fundamental issue of whether rights can be recognized if the parties on the other side of this right were never part of the original discussion. If there is a unilateral play, however, the answer depends on whether we recognize remedy without rights, which is part of what the targeted assassination issue is centered upon. The context here takes us to the next level of discussion visà-vis targeted killing - can we locate a right, even without recognizing its emergence?

The contemporary human rights jurisprudence guides us to deal with a set of doctrinal conditions along the lines of which each individual human, functional combatant, or non-functional combatant, must be allowed to evolve within a physical space. By virtue of rights that emanate from being in a physical space, the doctrinal developments of HRL are at odds with a "lack of rights" or "suspension of rights" construct used in framing a paradigm of targeted killing. We are not necessarily focusing on the severity of the punishment that may be the logical outcome for some of these functional combatants, or by following the logical outcome of a causal chain where people's lives may actually be at stake. However, not having the adequate procedure to get to that endpoint would defy logic according to contemporary human rights jurisprudence. Thus, while we might locate inherent rights to life for functional combatants, its counterpart - the right to target killing by the state is not flowing so spontaneously after all, despite the exigencies and shaping effect of an apocalyptic future propagated by the states. Therefore, I remain convinced the right to targeted killing does not exist under the auspices of international law as we know of it today.

249. See Narrative of Dehumanization, supra note 8, at 193-96. 